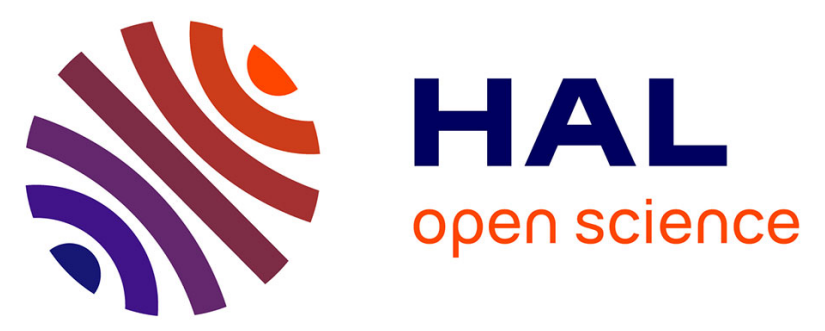

\title{
Anthropogenic methane plume detection from point sources in the Paris megacity area and characterization of their $\delta 13 \mathrm{C}$ signature
}

\author{
Irène Xueref-Remy, Giulia Zazzeri, Francois-Marie Breon, Felix R. Vogel, \\ Philippe Ciais, David Lowry, Euan G. Nisbet
}

\section{To cite this version:}

Irène Xueref-Remy, Giulia Zazzeri, Francois-Marie Breon, Felix R. Vogel, Philippe Ciais, et al.. Anthropogenic methane plume detection from point sources in the Paris megacity area and characterization of their $\delta 13 \mathrm{C}$ signature. Atmospheric Environment, 2020, 222, pp.546518. 10.1016/j.atmosenv.2019.117055 . hal-02335881

\section{HAL Id: hal-02335881 \\ https://hal-amu.archives-ouvertes.fr/hal-02335881}

Submitted on 28 Oct 2019

HAL is a multi-disciplinary open access archive for the deposit and dissemination of scientific research documents, whether they are published or not. The documents may come from teaching and research institutions in France or abroad, or from public or private research centers.
L'archive ouverte pluridisciplinaire $\mathbf{H A L}$, est destinée au dépôt et à la diffusion de documents scientifiques de niveau recherche, publiés ou non, émanant des établissements d'enseignement et de recherche français ou étrangers, des laboratoires publics ou privés. 


\title{
1 Anthropogenic methane plume detection from point 2 sources in the Paris megacity area and characterization of 3 their $\delta^{13} \mathrm{C}$ signature
}

\author{
I. Xueref-Remy ${ }^{a, b}$, \\ G. Zazzeri ${ }^{\text {c,d }}$, F.M. Bréon ${ }^{a}$, F. Vogel ${ }^{a, e}$, P. Ciais ${ }^{a}$, D. Lowry
} ${ }^{c}$ and E.G. Nisbet ${ }^{c}$

${ }^{a}$ Laboratoire des Sciences du Climat et de l'Environnement (LSCE), Gif-sur-Yvette, France

${ }^{b}$ Now at : Aix Marseille Univ, Avignon Université, CNRS, IRD, Institut Méditerranéen de Biodiversité et d'Ecologie marine et continentale (IMBE), Marseille, France

${ }^{c}$ Royal Holloway, University of London (RHUL), United Kingdom

${ }^{d}$ Now at : Department of Physics and Grantham Institute, Imperial College London, United Kingdom

${ }^{e}$ Now at : Climate Research Division, Environment and Climate Change Canada, Toronto, Canada

*Contact author : Irène Xueref-Remy (irene.xueref-remy@imbe.fr, +33 442908462).

\section{Abstract}

Mitigating anthropogenic methane emissions is one of the available tools for reaching the near term objectives of the Paris Agreement. Characterizing the isotopic signature of the methane plumes emitted by these sources is needed to improve the quantification of methane sources at the regional scale. Urbanized and industrialized regions such as the Paris megacity are key places to better characterize anthropogenic methane sources. In this study, we present the results of the first mobile surveys in the Paris region, assessing methane point sources from 10 landfills (which in the regional inventory are the main emission sector of methane in the region), 5 gas storage sites (supplying Paris) and 1 waste water treatment (WWT) facility (Europe's largest, second worldwide). Local atmospheric methane concentration (or mixing ratio) enhancements in the source plumes were quantified and their $\delta^{13} \mathrm{C}$ in $\mathrm{CH}_{4}$ (further noted $\delta^{13} \mathrm{CH}_{4}$ ) signature characterized. Among the 10 landfills sampled, at 6 of them we detected atmospheric methane local enhancements ranging from 0.8 to 8.5 parts per million (ppm) with $\delta^{13} \mathrm{CH}_{4}$ signatures between $-63.7 \pm 0.3$ permils (\%) to $58.2 \pm 0.3 \%$. Among the 5 gas storage sites surveyed, we could observe that 3 of them were leaking methane with local methane concentration enhancements ranging from 0.8 to $8.1 \mathrm{ppm}$ and $\delta^{13} \mathrm{CH}_{4}$ signatures spanning from $-43.4 \pm 0.5 \%$ to $-33.8 \pm 0.4 \%$. Dutch gas with a $\delta^{13} \mathrm{CH}_{4}$ signature of $-33.8 \pm 0.4 \%$ (typical of thermogenic gas) was also likely identified. The WWT site emitted local methane enhancements up to $4.0 \mathrm{ppm}$. For this site, two $\delta^{13} \mathrm{CH}_{4}$ signatures were determined as $-51.9 \pm 0.2 \%$ and $-55.3 \pm 0.1 \%$, typical of a biogenic origin. About forty methane plumes were also detected in the Paris city, leading to local concentration enhancements whose origin was in two cases interpreted as natural gas leaks thanks to their isotopic composition. However, such enhancements were much less common than in cities of North America. More isotopic surveys are needed to discriminate whether such urban methane enhancements are outcoming from gas line leaks and sewer network emanations. Furthermore, our results lead us to the conclusion that the regional 
emissions inventory could underestimate methane emissions from the WWT sector. Further campaigns are needed to assess the variability and seasonality of the sources and of their isotopic signature, and to estimate their emissions using methods independent of the inventory.

Keywords: methane sources, isotopes, mobile campaigns, Paris

\section{Highlights:}

- CH4 plumes were located on anthropogenic sites in the Paris megacity

- A mobile CRDS analyzer was used to detect local methane enhancements in the plume

- CRDS and GC-IRMS measurements were performed to provide source isotopic signatures

- These results provide independent constraints to quantify regional methane sources.

\section{1- Introduction}

Methane $\left(\mathrm{CH}_{4}\right)$ is, after carbon dioxide $\left(\mathrm{CO}_{2}\right)$, the second anthropogenic greenhouse gas (GHG) contributing to human-induced global warming. According to Saunois et al. (2017), more than $60 \%$ of global $\mathrm{CH}_{4}$ emissions are attributed to human activities. Mitigating anthropogenic methane emissions is therefore of importance for reaching the near term objectives of the Paris Agreement and fighting climate change. Since the pre-industrial era, the global average atmospheric concentration (or mixing ratio) of methane has more than doubled to reach almost 1850 parts per billion (ppb) in 2017 (Dlugokencky, 2018). Methane has a global warming potential much larger than that of carbon dioxide ( 28 times more on a 100-year horizon ; Saunois et al, 2016), despite its shorter ( $\approx 10$ years) atmospheric lifetime (Gasser et al., 2017). Therefore, effective measures to decrease $\mathrm{CH}_{4}$ emissions to the atmosphere are expected to have a rapid impact on mitigating global warming, making $\mathrm{CH}_{4}$ a target for immediate emission reduction efforts (Montzka et al., 2011 ; Nisbet et al., 2019).

After a fast increase of atmospheric methane in the $20^{\text {th }}$ century followed by the stabilisation of the $\mathrm{CH}_{4}$ global mean concentration between 1999 and 2006, a rapid increase in the atmospheric methane concentration has occured again since 2007 (Nisbet et al., 2014; Nisbet et al. 2016). However, the causes for the changes in the methane growth rate are poorly understood. A major effort is needed in quantifying individual methane sources (Houweling et al., 2017 ; Dlugokencky et al., 2011), taking into account the high variability of methane emissions at the regional and global scales.

Anthropogenic methane emissions come from leaks from the fossil fuel sector such as oil and gas extraction sites, coal mines, gas storage facilities and distribution network, refineries, (Schwietzke et al., 2017), landfills, waste water processing plants and ruminants (Saunois et al., 2017). Emissions data are mostly developed using a "bottom-up" approach, which combines local activity statistics (e.g.volume of gas used, etc.) multiplied by a specific emission factor for each emission sector. The source quantification and partitioning for methane emissions is mainly based on such bottom-up inventories that may underestimate emissions by 50 to $70 \%$ at the national level (Miller et al., 2013 ; Karion et al., 2013). Also, these estimates are often reported without uncertainties, as the lack of independent data makes it not possible to assess those correctly. Furthermore, emission factors are most often defined from measurements carried out on a limited number of sources that are taken as representative of an emission sector, or based upon benchmarked measurements or theoretical calculations. The IPCC guidelines provide default (Tier 1) emission factors 
estimates that are used in most emission inventories, if Tier 2 or Tier 3 (i.e. region-specific or site-specific emission factors) is not available (IPCC, 2006). However, these Tier 1 estimates do not reflect the variability of emission factors for the different sources at the regional or national scales. Therefore, assessing emissions inventories by independent methods is needed.

Atmospheric "top-down" approaches, based on a combination of surface measurements with atmospheric transport modeling, represent an appropriate tool to estimate $\mathrm{CH}_{4}$ emissions (e.g. Houweling et al., 2017). The analysis of carbon stable isotopes in $\mathrm{CH}_{4}$ provides a further independent constraint on the budget of atmospheric methane, as the ${ }^{13} \mathrm{C}$ content of methane is source dependent (e.g. Lassey et al., 2011), allowing different source types to be distinguished: biogenic/microbial methane sources are strongly ${ }^{13} \mathrm{C}$ depleted $\left(\delta^{13} \mathrm{CH}_{4}=-70\right.$ to -50 permils, noted \%o) while pyrogenic $\mathrm{CH}_{4}$ sources (from incomplete combustion) and thermogenic sources (oil and gas) are less depleted in ${ }^{13} \mathrm{C}$ $\left(\delta^{13} \mathrm{CH}_{4}=-30\right.$ to $-15 \%$ and -50 to $-30 \%$, respectively) (e.g. Lopez et al., 2017 ; Zazzeri et al., 2015 ; Zazzeri et al., 2017). This information can be used in atmospheric modelling to independently evaluate and improve emissions estimates at the global and regional scales (e.g. Mikaloff Fletcher, 2004; Bousquet et al., 2006; Monteil et al., 2011 ; Nisbet et al., 2016 ; Schwietzke et al., 2016). However, the uncertainties on the $\delta^{13} \mathrm{CH}_{4}$ source signatures used as inputs in the global modeling framework are large, as each source type can vary substantially at the regional scale in function of several factors (methane geographical origine, formation process, season, secondary alteration - e.g. Whiticar, 1999 ; Fisher et al., 2011 ; Zazzeri et al., 2015 ; Lopez et al., 2017). Therefore, the determination of the specific $\delta^{13} \mathrm{CH}_{4}$ signatures of regional sources is needed (and their time variation, ideally) for a source apportionment of methane emissions at the regional scale.
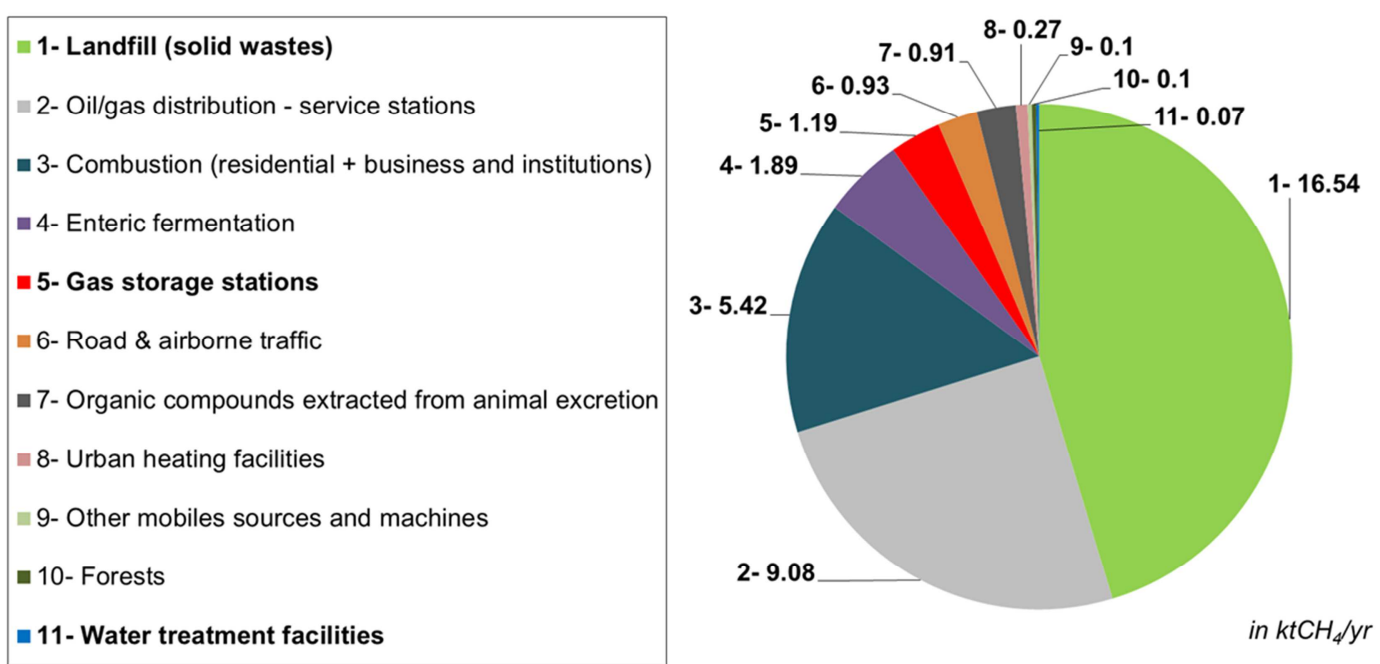

Figure 1. Sources of methane in lle-de-France, in $k t C H_{4} / y r$ (AIRPARIF, 2013 inventory).

As most of methane emissions come from human activities, urbanized and industrialized regions are key regions to carry out atmospheric surveys. Cities are the major source of GHG emissions globally and constitute important targets for GHG emissions mitigation [Duren and Miller, 2012]. Reducing urban emissions of $\mathrm{CO}_{2}$, the most important GHG, has been the focus of several cities, but methane emissions have been largely neglected until recently (e.g. von Fischer et al., 2017; Weller et al., 2018). We do not know 
precisely which sources and how much these sources contribute to cities methane budget. This makes the use of global modelling for the estimation of regional sources in urbanized areas quite complicated (Townsend-Small et al., 2011b; Townsend-Small et al, 2012), as for example in Los Angeles where large scale transport models underestimate the observed $\mathrm{CH}_{4}$ concentration (Hsu et al., 2010). Urbanized and industrialized regions are equipped with facilities that represent widespread sources of methane, including landfill sites, gas storage and distribution networks, WWT plants, heating systems and vehicles. Stable isotopic signatures provide an important constraint in the evaluation of local methane sources. Previous $\delta^{13} \mathrm{CH}_{4}$ sources studies in urbanized areas have been carried out through intensive field campaigns, for example in the London region (Lowry et al., 2001 ; Zazzeri et al., 2017), in Boston (Phillips et al., 2013 ; Boothroyd et al., 2018), in Washington DC (Jackson et al., 2014) and in Los Angeles (Townsend-Small et al., 2012).

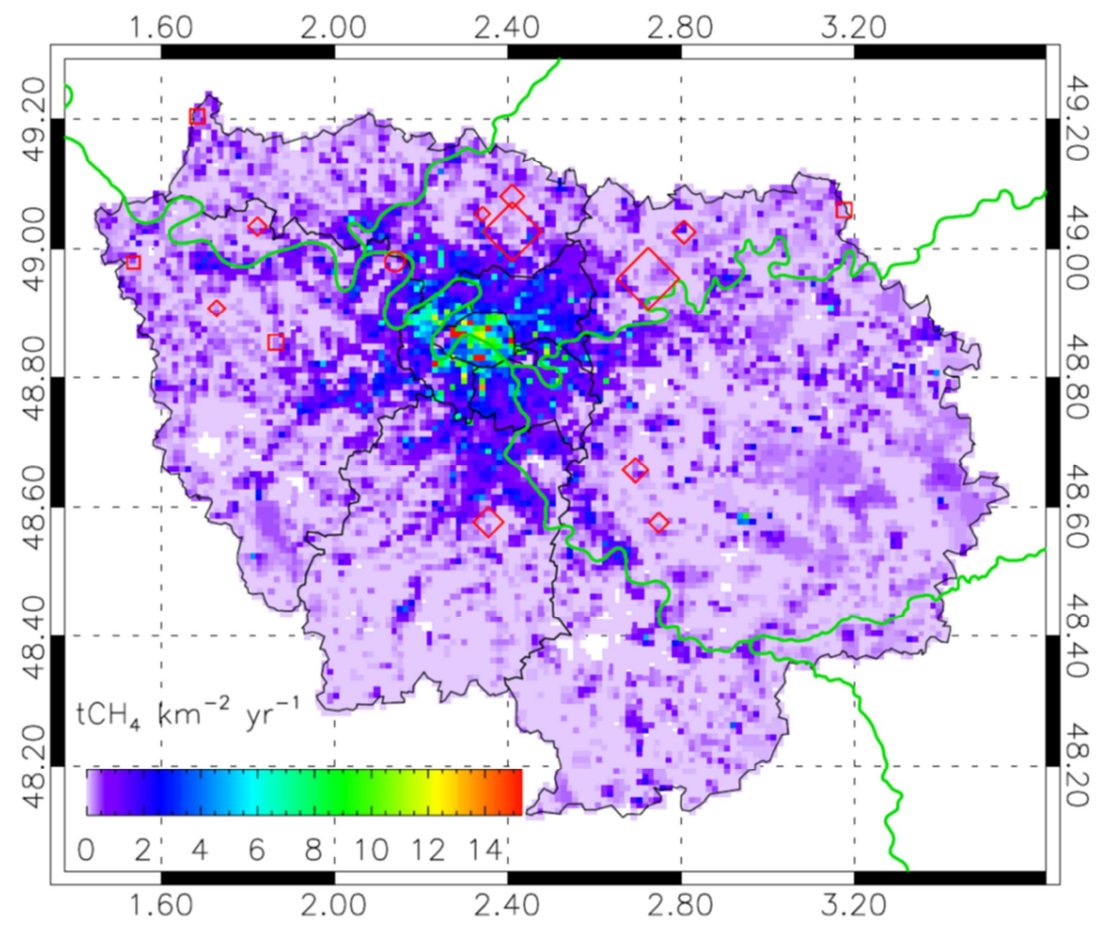

Figure 2. Methane emissions in IDF according to the AIRPARIF 2013 emissions inventory. Losanges indicate the positions of landfills, squares the ones of the gas storage sites and the circle the one of the Achères waste water treatment facility, that were all surveyed in the framework of this study. Another gas storage site located out of IDF further in the North was also surveyed (see Table 2). The symbol size is calibrated to the emissions given by AIRPARIF inventory.

To our best knowledge, this study is the first one on characterizing the individual methane sources and their $\delta^{13} \mathrm{CH}_{4}$ signature in the Paris megacity region, and on assessing possible leaks from the Paris gas network underground lines as it was done in other urban areas (e.g. Phillips et al., 2013 ; Jackson et al., 2014). With 12 million inhabitants, Paris is the third biggest megacity in Europe and a large source of GHG (e.g. Xueref-Remy et al., 2018). It is located in the lle-de-France region (IDF) which represents $2 \%$ of the national territory. According to the regional air quality agency (AIRPARIF, http://www.airparif.asso.fr/), methane emissions in IDF (Fig.1) are $36.5 \mathrm{ktCH}_{4} / \mathrm{yr}$ and contribute for $2 \%$ of GHG emissions from IDF. Fig. 2 shows the methane annual emissions per square kilometer from the 
AIRPARIF 2013 inventory. According to this inventory, 45\% of these emissions result from solid waste landfills, $25 \%$ from oil/gas distribution in vehicles refuelling stations, $15 \%$ from combustion processes in buildings and $5 \%$ from ruminants. Then follows the gas storage sector estimated to emit $3 \%$ of the regional methane emissions. Note that there is no coal mine in the Paris region. Several other minor sectors follow, including water treatment facilities estimated to emit $70 \mathrm{~kg} \mathrm{CH} / \mathrm{yr}$ i.e. $0.2 \%$ of $\mathrm{CH}_{4}$ emissions in IDF (a surprising low estimate). Unlike diffuse sources (e.g. enteric fermentation, buildings, traffic) which are widely distributed, landfills, WWT sites and gas extraction and compression facilities are intense localized sources. By using atmospheric measurements, methane plumes from those sources can be detected and isotopically characterized (e.g. Zazzeri et al., 2015 ; Lopez et al., 2017). Note that fuel service stations are also point sources, but they are so numerous in IDF that this makes it difficult to survey them exhaustively. Furthermore, according to previous studies (Phillips et al., 2013 ; Jackson et al., 2014 ; Eijo-Rio et al., 2015 ; McKain et al., 2015 ; Boothroyd et al., 2018), urbanized areas may also be affected by leaks on gas storages sites and gas distribution urban networks, as well as sewer networks within the city itself whose emissions are not reported in the inventories.

In this study, we report the $\delta^{13} \mathrm{CH}_{4}$ emissions signature from non-agricultural intense localized sources (landfill, gas storage and WWT sites, cf Fig.2) in the Paris megacity region calculated by combining CRDS (Cavity Ring Down Spectroscopy) and GC-IRMS (Gas chromatography and Isotope Ratio Mass Spectrometry) measurements. We also assessed whether gas distribution lines and sewer networks were also sources of methane in the Paris city. The measurements were collected between December 2012 and December 2015 through several intensive campaigns using mobile in-situ $\mathrm{CRDS} \mathrm{CH}_{4}$ and $\delta^{13} \mathrm{CH}_{4}$ analyzers and an air bag sampling set-up onboard a vehicle for accurate measurements of $\delta^{13} \mathrm{CH}_{4}$ in the laboratory with GC-IRMS, using a similar design as the one described in Zazzeri et al. (2015). The material and methods are detailed in Section 2. Results are presented in Section 3. We discuss and compare our results with those of previous studies and the AIRPARIF 2013 inventory in section 4. We conclude on the benefits and limitations of such mobile campaigns and CRDS and GC-IRMS technics for better inferring regional $\mathrm{CH}_{4}$ budgets.

\section{2- Material and methods}

\subsection{Methodology}

The isotopic ${ }^{13} \mathrm{C}$ composition of 16 individual intense localized methane sources (5 gas storage sites, 10 landfills and 1 large WWT site) and prospective line sources from the gas network underground lines and sewer networks of the Paris megacity region was analyzed through a series of 6 mobile car campaigns (17-20 December 2012 ; 12-15 May 2014 ; 10-11 August 2015; 8-9 September 2015; 19-23 November 2015 ; and 7-10 December 2015) through a Keeling plot approach (Keeling, 1958). Each site was studied individually. $\mathrm{CH}_{4}$ concentration measurements were carried out accross the atmospheric $\mathrm{CH}_{4}$ plume emitted by each site according to wind direction and speed measurements performed simultaneously, allowing us to quantify the local enhancement of methane concentration above background downwind of each source. Since these enhancements are quite large, the methane concentration is given in parts per million (ppm), which is the unit commonly used in similar studies and delivered by the CRDS analyzer (e.g. Zazzeri et al, 2015). If the $\mathrm{CH}_{4}$ 
enhancement was strong enough ( $\geq 0.5$ parts per million $(\mathrm{ppm})$, we performed isotopic measurements along the concentration gradient. Note that this study did not aim at characterizing precisely the amplitude of the source plume, which depends largely on meteorological conditions and conditions of sampling. The objective of the present study was rather to detect the source plume emitted by each site and to characterize its $\delta^{13} \mathrm{CH}_{4}$ signature.

The isotopic measurements must have a sufficient precision to be used for source apportionment. The difference between the different $\delta^{13} \mathrm{CH}_{4}$ sources signature is about 10-15 $\%$. The spatio-temporal variability for each source type is a few \%० (2-7\%。; e.g. Arata et al, 2016). Given these numbers, the ideal precision we aimed at was smaller than $\pm 0.8 \%$ on the source defined by a Keeling Plot approach (Keeling, 1958) : this requires a high precision on the $\delta^{13} \mathrm{CH}_{4}$ measurements, achievable using the GC-IRMS facility of RHUL, given a $\mathrm{CH}_{4}$ concentration enhancement along the emission plume higher than $0.5 \mathrm{ppm}$ above background (Zazzeri et al., 2015). The GC precision on the concentration measurements is \pm $0.5 \mathrm{ppb}$ and the IRMS precision on the isotopic data is $\pm 0.05 \%$ for each measurement ; using these data, a precision as low as $\pm 0.1 \%$ on the $\delta^{13} \mathrm{CH}_{4}$ source signature could be obtained for certain sites by the Keeling plot approach (see sections 2.4 .2 and 3.1). The CRDS analyzer (model G2132-i by PICARRO) could not reach such a precision but could be used for the source $\delta^{13} \mathrm{CH}_{4}$ signature determination if the increase in the $\mathrm{CH}_{4}$ concentration due to the studied source is higher than $1.5 \mathrm{ppm}$ (PICARRO, personal communication). According to PICARRO, the precision of the datasets used in this study is $5 \mathrm{ppb}+0.05 \%$ of reading on the 5 min average concentration measurements; $\pm 0.8 \%$ on 5 min average isotopic measurements ; and a resulting precision of $\pm 2.0 \%$ to $\pm 3.7 \%$ on the source signature.

On the majority of landfill sites and gas storage sites, and on the WWT site, and whenever the local methane concentration enhancements were above $0.5 \mathrm{ppm}$, air samples were collected into bags (integration time of about 30 seconds) then analyzed by GC-IRMS at RHUL. Such samples were collected during 4 days in December 2015 campaign, thanks to the INGOS TNA program (https://www.ingos-infrastructure.eu/access/). CRDS data were collected during all the campaigns presented in this study in the framework of the CARBOCOUNT-CITY project. Regarding the assessment of possible leaks from Paris underground gas lines and sewer networks and from the WWT site, mobile $\mathrm{CH}_{4}$ measurements were conducted in the Paris city streets to detect possible $\mathrm{CH}_{4}$ plumes and to attempt to characterize their $\delta^{13} \mathrm{CH}_{4}$ isotopic signature, but only using CRDS measurements.

Furthermore, over the recent years, some studies reported that CRDS $\delta^{13} \mathrm{CH}_{4}$ measurements are affected by the presence in the sampled air of ethane together with methane (Rella et al., 2015 ; Assan et al., 2017). Ethane is co-emitted with methane from fossil fuel sources. Unfortunately, we did not have ethane measurements to apply the correction for ethane on methane CRDS measurements proposed by Assan et al. (2017). Therefore, the isotopic composition of the air samples collected on 6 of our selected sites, analyzed by GC-IRMS, was compared to the isotopic CRDS data for cross-validation of both methods and to assess independently the uncertainty of the CRDS data.

\subsection{Site identification and selection}


In this study, we focus on the main regional landfills, on the four gas storage sites plus a fifth one located outside IDF but that contributes to feed the Paris natural gas network, Paris city underground gas lines and sewer networks, and a peri-urban WWT site that is the biggest one in Europe. According to the AIRPARIF 2013 emissions inventory, localized intense sources are the main emitter of methane in IDF (Fig.1). These sources are mostly landfills for solid wastes, and represent the most important methane emissions sector in IDF (Fig.1). In landfill sites, part of the wastes that cannot be recycled nor valorized energetically or biologically (e.g. compost) is first treated to reduce its potential toxicity and then buried in soil. Landfills are estimated by the AIRPARIF 2013 inventory to emit $16.54 \mathrm{ktCH}_{4} / \mathrm{yr}$ from 10 sites. $44 \%$ of those are emitted by landfills located in the Seine-et-Marne department (77) alone (AIRPARIF emissions inventory, 2013), the eastern part of IDF.

Another type of point sources are gas storage sites. There are 4 of them in IDF and a $5^{\text {th }}$ one in the Hauts-de-France (HDF) region just north of IDF, which all supply the Paris megacity gas network (https://www.storengy.com/countries/france/en/our-sites.html). These sites are reported to leak and emit $1.17 \mathrm{ktCH}_{4} / \mathrm{yr}$ by the inventory which corresponds to more than $98 \%$ of the fossil fuels extraction and compression sectors (Fig.1).

A third type of point methane sources of interest is WWT facilities. The IDF region comprises the biggest WWT plant in Europe, which is located in Achères (Table 4). In the AIRPARIF 2013 inventory, the WWT facility sector comprises one emission point that corresponds to the Achères facility with estimated emissions of $0.066 \mathrm{ktCH}_{4} / \mathrm{yr}$ i.e. $0.2 \%$ of the regional methane emissions. The access to these sites are usually restricted and requires specific authorization. However, the methane plume coming from the site can be detectable while driving downwind of it.

The diffuse source types given in Fig. 1 contain road and airborne traffic, but gas leaks from gas distribution pipes, sewer networks and residential buildings are not considered in the AIRPARIF 2013 emissions inventory. These are very poorly known potential sources, and have been shown to represent large non-reported sources in other cities like in Boston (Phillips et al., 2013) and in New-York City (Jackson et al., 2014). In this study, a systematic street survey in Paris was carried out in order to check for possible methane leaks from the gas distribution lines and sewer networks.

\subsubsection{Landfill sites}

In landfills, the decomposition of the organic waste by fermentation occurs in a ground-dug locker after it has been compressed. It produces a mix of gases named "biogas", mostly made of methane (50 to 70\%) in the case of French facilities (e.g. https://www.notre-planete.info/ecologie/dechets/methanisation-biogaz.php). French emission regulation policies state that landfill managers should install inside the locker efficient biogas capture systems, once the locker is fully filled and recovered by a re-vegetalisation process. The captured biogas is then used to produce energy (e.g. burned to produce electricity, or some cases for heat co-generation). However, these systems use only part of the trapped biogas. The rest is being flared using processes that are not stricly regulated by the law. Furthermore, despite the vegetal cover set on the filled lockers, biogas might leak into the atmosphere, contributing to diffuse methane emissions from the landfill site (https://www.oieau.org/eaudoc/system /files/documents/45/226168/226168_doc.pdf).

The main landfill sites of IDF included in the AIRPARIF 2013 emissions inventory match the 10 sites for storage of non-dangerous wastes existing in IDF identified in the Atlas delivered by the Regional Observatory of Wastes (ORDIF, 2013), except one, which 
according to Airparif, is located outside of IDF. This site very likely corresponds to the $10^{\text {th }}$ site of the ORDIF (2013) Atlas, called Isles-les-Meldeuses.

Table 1 gives the list of the 10 sites that we selected for our mobile survey, their location, and emission estimates from the Airparif 2013 emissions inventory. 9 sites out of 10 are the largest landfills currently active in IDF (Brueil-en-Vexin and Guitrancourt are counted as one in the table as both sites are very closed one from each other and the second one now replaces the first one). The $10^{\text {th }}$ selected site is Epinay-Champlatreux, a landfill for nondangerous wastes that was closed on 31 December 2008 and that is counted as an active methane source in the Airparif 2013 inventory (http://www.dechetcom.com/comptes/icamille/env idf3.pdf).

\begin{tabular}{|c|c|c|c|c|}
\hline Site code & $\begin{array}{c}\text { Name (region, } \\
\text { department code) }\end{array}$ & $\begin{array}{c}\mathrm{ktCH}_{4} / \mathbf{y r} \\
\text { (AIRPARIF) }\end{array}$ & Latitude $\left({ }^{\circ} \mathbf{N}\right)$ & Longitude $\left({ }^{\circ} \mathrm{E}\right)$ \\
\hline \multirow[t]{2}{*}{ L1 } & Claye-Souilly (IDF, 77) & 5.58 & 48.954 & 2.724 \\
\hline & & & 48.955 & 2.732 \\
\hline \multirow[t]{2}{*}{ L2 } & Le Plessis-Gassot & 5.00 & 49.026 & 2.410 \\
\hline & (IDF, 95) & & 49.047 & 2.410 \\
\hline \multirow[t]{2}{*}{ L3 } & Vert-le-Grand & 1.33 & 48.577 & 2.356 \\
\hline & (IDF, 91) & & 48.587 & 2.381 \\
\hline \multirow[t]{2}{*}{ L4 } & Soignolles-en-Brie & 0.93 & 48.657 & 2.695 \\
\hline & (IDF, 78) & & 48.641 & 2.739 \\
\hline \multirow[t]{2}{*}{ L5 } & Epinay-Champlatreux & 0.83 & 49.080 & 2.411 \\
\hline & $\begin{array}{c}\text { (IDF, 95) closed on } \\
31 / 12 / 2008 .\end{array}$ & & 49.051 & 2.421 \\
\hline \multirow[t]{2}{*}{ L6 } & Monthyon & 0.77 & 49.025 & 2.807 \\
\hline & $($ IDF, 77) & & 49.022 & 2.798 \\
\hline \multirow[t]{2}{*}{ L7 } & Fouju-Moisenay - Blandy & 0.58 & 48.576 & 2.749 \\
\hline & (IDF, 77) & & 48.576 & 2.751 \\
\hline \multirow[t]{4}{*}{ L8 } & Brueil-en-Vexin (IDF, 78) & 0.50 & 49.034 & 1.823 \\
\hline & from 1974 to $24 / 2 / 2014$ & & 49.017 & 1.805 \\
\hline & now replaced by & & 48.989 & 1.796 \\
\hline & & 0.22 & 49.011 & 1.796 \\
\hline \multirow[t]{2}{*}{ L9 } & Isles-les-Meldeuses & 0.41 & 48.908 & 1.729 \\
\hline & (IDF, 77) & & 49.002 & 3.031 \\
\hline \multirow[t]{2}{*}{ L10 } & Moisselles* $^{*}$ IDF, 95) & 0.32 & 49.053 & 2.342 \\
\hline & Real location : Attainville & & 49.050 & 2.352 \\
\hline
\end{tabular}

Table 1. List and coordinates of the main landfill sites in IDF for the storage of nondangerous wastes, obtained by combining the AIRPARIF 2013 emissions inventory and ORDIF (2013) information, and their annual $\mathrm{CH}_{4}$ emissions estimates from AIRPARIF 2013 inventory. The actual geographical coordinates are given on the second line of each site.

\subsubsection{Gas storage sites}

There are 4 big gas storage sites in lle-de-France (according to the EPA classification, these would fit into the "city gates" and "underground gas storages" terms of the transmission source sector - see https://www.epa.gov/natural-gas-starprogram/overview-oil-and-natural-gas-industry). These sites are filled in summertime and 
used in wintertime to supply gas to the IDF and Normandie (West of IDF) regions. A $5^{\text {th }}$ gas storage site located in the Hauts-de-France (HDF) region (North of IDF) partly supplies gas to lle-de-France as well. These sites are operated by STORENGY, a sub-contractor of Gaz De France (http://www.storengy.com/fr/qui-sommes-nous/nos-implantationsindustrielles.html). They are made of a number of sinks filled with compressed gas. Table 2 gives for each site the location, capacity of gas storage, number of sinks operated, emission estimates from the Airparif 2013 emissions inventory, ordered by the site capacity, from the largest to the smallest.

\begin{tabular}{cccccc}
\hline $\begin{array}{c}\text { Site } \\
\text { code }\end{array}$ & $\begin{array}{c}\text { Name (region, } \\
\text { department code) }\end{array}$ & $\begin{array}{c}\text { Capacity }\left(\mathbf{M m}^{3}\right) \\
\text { \& sinks number }\end{array}$ & $\begin{array}{c}\mathbf{k t C H}_{4} / \mathbf{y r} \\
\text { (AIRPARIF) }\end{array}$ & $\begin{array}{c}\text { Latitude } \\
\left({ }^{\circ} \mathbf{N}\right)\end{array}$ & $\begin{array}{c}\text { Longitud } \\
\left({ }^{\circ} \mathrm{E}\right)\end{array}$ \\
\hline S1 & Gournay-sur- & 3500 & - & - & - \\
& Aronde (HDF, 60) & 59 & & 49.528 & 2.701 \\
\hline S2 & Germigny-sous- & 2200 & 0.32 & 49.059 & 3.176 \\
& Coulombs (IDF, 77) & 22 & & 49.056 & 3.173 \\
\hline S3 & Saint-Illiers-la-ville & 1200 & 0.23 & 48.979 & 1.537 \\
& (IDF, 78) & 31 & & 48.985 & 1.551 \\
\hline S4 & Beynes (IDF, 78) & 1185 & 0.32 & 48.854 & 1.865 \\
& & 36 & & 48.844 & 1.874 \\
\hline S5 & Saint-Clair-sur-Epte & 1000 & 0.30 & 49.204 & 1.684 \\
& (IDF, 95) & 14 & & 49.204 & 1.707 \\
\hline
\end{tabular}

Table 2. List and coordinates of the gas storage sites ordered by their capacity as given by STORENGY. The first lat/long line of each site indicates the position given by the AIRPARIF 2013 emissions inventory. The actual geographical coordinates are given on the second line of the corresponding cell. The Gournay-sur-Aronde site is located in the Hauts-de-France region (HDF) and not in the IDF region, therefore it is not listed in the AIRPARIF database.

\subsubsection{Gas distribution lines (and sewer networks)}

The gas distribution in Ile-de-France is at the charge of GRDF (Gaz Réseau Distribution France, https://www.grdf.fr/). Detailed map of gas pipelines is not available. The most detailed available map we could find is available from the following link: http://www.cre.fr/reseaux/infrastructures-gazieres/description-generale\#section5. The main pipelines of Ile-de-France appear to be sited along highways. Secondary pipelines are likely distributed along streets in urbanized areas, but a higher resolution map was not available. According to previous studies, gas leaks can occur anywhere in a city (Phillips et al., 2013 ; Jackson et al., 2014). We thus sampled streets in one to several districts in the Paris inner city area for each campaign day. We also sampled on the road that encompasses Paris city and also the city of Montrouge close to Paris in the south/southeast (Table 3). Note that there is a possibility that the sewer networks would also emit methane, but then the methane isotopic signature would be much more depleted than the one outcoming from gas leaks. This property can be used to discriminate gas line and sewer network sources.

\begin{tabular}{cc}
\hline Site code & Location \\
\hline G1 & BP (ring road) \\
\hline G2 & Paris districts \\
\hline G3 & Montrouge (SSE of Paris)
\end{tabular}

Table 3. List of the gas line sites (and sewer network sites) 
WWT involves the degradation of organic matter of the effluents in anaerobic conditions that releases biogenic methane emissions. The different steps are explained in details for instance in Ars (2017). The SIAAP (Syndicat Interdépartemental pour l'Assainissement de l'Agglomération Parisienne) is the main operator of WWT facilities in IDF. There are 5 WWT plants (Seine Crésillons, Seine Aval, Seine Amont, Seine centre and Marne Aval) in IDF, the biggest WWT facility being Seine Centre, located at Achères (http://www.veoliaeau.com/medias/ dossiers/acheres.htm). It is is also the biggest in Europe (and the second worldwide). The Achères WWT facility is located on two sub-sites which coordinates are given in Table 4. Methane emissions from this facility have not been isotopically characterized before this study and therefore it was a target of our mobile campaigns. In this study, we were able to characterize the $\delta^{13} \mathrm{CH}_{4}$ signature of the second sub-site $\left(48.986^{\circ} \mathrm{N}, 2.124^{\circ} \mathrm{E}\right)$.

\begin{tabular}{lllll}
\hline Site code & Name & $\mathbf{k t C H}_{4} / \mathbf{y r}$ (AIRPARIF) & Latitude $\left({ }^{\circ} \mathbf{N}\right)$ & Longitude $\left({ }^{\circ} \mathrm{E}\right)$ \\
\hline W1 & Achères & 0.066 & 48.973 & 2.167 \\
& & & 48.973 & 2.166 \\
& & & $\& 48.986$ & $\& 2.124$ \\
\hline
\end{tabular}

Table 4. Coordinate of the selected WWT site and its annual methane emissions estimate from the AIRPARIF (2013) inventory. The first lat/long line indicates the position of the site given by the AIRPARIF inventory. The actual geographical coordinates of the site are indeed double and are given on the second and third lines of the lat/long cells.

\subsection{Instrumentation}

During the mobile campaigns, we used the Picarro Investigator ${ }^{\mathrm{TM}}$ Unit (proprietary product of Picarro) which is made of hardware components and a cloud based software for providing an integrated solution to $1 /$ treat and control the datasets ; $2 /$ detect and locate methane enhancements above background ; and 3/ distinguish between biogenic and thermogenic methane sources of these enhancements (Arata et al, 2016). The hardware components consist of a car equiped with a Picarro G2132-i CRDS (Cavity Ring Down Spectroscopy) analyzer (https://naturalgas.picarro.com/overview). This analyzer was customized by PICARRO specifically for the Investigator Unit to support mobile measurements. The analyzer was powered directly from the car through a $12-220 \mathrm{~V}$ power transformer. The air inlet was attached on a 1-m height mast mounted on the roof of the vehicle. It was made of a $1 / 4$ inch outer diameter (O.D.) and 2-m length Nylon tube equiped with a $2 \mu \mathrm{m}$ Swagelock particle filter and connected to the entrance of the analyzer inside the car. The car was also equiped with a Climatronics sonic anemometer for wind measurement and a Hemisphere GPS receiver fixed on the mast, which allowed a precise determination of the car location. The analyzer was calibrated before the campaigns with a tank supplied by Matheson whose methane concentration was $19.6+/-0.015$ ppm and $\delta^{13} \mathrm{C}$ content was -32.6 $+/-0.05 \%$. During the campaigns, this tank was used to detect any instrumental drift, but the Picarro analyzer showed a stable behavior. This instrument was designed to monitor in two modes separately. In the first mode, only $\mathrm{CH}_{4}$ concentrations were monitored while the car was moving. The analyzer flow rate was increased to $3.5 \mathrm{~L} / \mathrm{min}$ and its frequency to $4 \mathrm{~Hz}$ to get a fast instrumental response, which gives a transport time in the tubing of $2 \mathrm{~s}$. The datasets were corrected for this delay. The car drove at $50 \mathrm{~km} / \mathrm{h}$ or less, which gives a maximum uncertainty of $28 \mathrm{~m}$ on the source location regarding the vehicle speed. Once a methane enhancement above background was detected, we drove again into it and much slower to make sure it was occurring at the same location. The occurrence of the methane 
enhancement was also confirmed by the isotopic measurements. To perform isotopic measurements, the car was stopped and the CRDS analyzer was turned into its second mode : the analyzer was coupled to a « Megacore " set-up based on a Dekabon tubing of 10 $\mathrm{m}$, that was collecting air while we were driving in the plume. In this second mode, once we were sure that we detected a persistent enhancement above background concentrations, the car was stopped, and the air of the "Megacore " was analyzed for its isotopic content at a flowrate of $25 \mathrm{~mL} / \mathrm{min}$. The flowing time of the air in the analyzer was used to reconstruct the location of each data point.

The data were collected through a bluetooth connection into a central onboard computer, which was also used to monitor the $\mathrm{CH}_{4}$ concentrations during the survey. The CRDS data were instantaneously sent by $3 G$ or $4 G$ connection to a cloud server. On this latter, a complex software called Pcubed (proprietary product of Picarro) was applied on the datasets to detect isolated peaks that could be attributed to an instrumental artefact (e.g. cell pressure or temperature instabilities) from longer methane enhancements above background that could be attributed to a methane source. Usually, the vibrations of the car do not generate peaks but could damage the mirrors and laser of the cavity; however, no such damage was observed during our campaigns.

After a methane enhancement was detected by CRDS, the car was driven back into it to collect air samples into bags at different locations of the enhancement and outside of it for background assessment. The concentration and $\delta^{13} \mathrm{C}$ content of atmospheric methane in the sample bags were analyzed at the RHUL laboratory straight after the sampling campaign, using the material and methods described in Zazzeri et al. (2015). The car was stopped during each bag sampling. The bags, made of Tedlar $(5 \mathrm{~L})$ were filled with outside air during $30 \mathrm{~s}$ each using a battery operated pump (KNF Neuberger), pumping air through a $1 / 4$ inch O.D. Nylon tube attached to the mast in the car. Before the filling, the full set-up was flushed with ambient air for 4 minutes in order to reach equilibrium between gas and solid phases. Five to twelve bags were filled for each identified plume. In total, heighty samples were collected. The isotopic measurements and Keeling plot analysis allowed calculation of a distinct isotopic signature for the main methane sources in the Paris region. The observed source isotopic signatures can be used also for the characterization of methane emissions in more densely populated areas and for regional modelling (see section 1).

The location of both CRDS analyser and air sampling inlets on the mast prevented the measurements to be contaminated by the car exhaust. When not driving during bag sampling, we paid attention to choose favorable conditions in order to prevent that the car exhaust plume was advected or thermally uplifted to the air line inlets location.

\subsection{Data analysis}

2.4.1 $\delta^{13} \mathrm{CH}_{4}$

By definition, the isotopic composition of methane is expressed in terms of a ratio in per mil (\%), using the $\delta$ notation (Pataki et al., 2003) :

$$
\delta=\left(R_{A} / R_{s t d}-1\right) \times 1000
$$


where $R_{A}$ denotes the isotopic ratio ${ }^{13} \mathrm{C} /{ }^{12} \mathrm{C}$ in $\mathrm{CO}_{2}$ derived by combustion of the methane sample. $R_{\text {std }}$ is the corresponding ratio in the V-PDB (Vienna Pee Dee Belemnite) standard. Isotopic signatures can vary over time and season : this is the case for landfill sites, due to changes in landfill management that result in the modification of the fraction of $\mathrm{CH}_{4}$ oxidised in the topsoil, and thus, of the $\delta^{13} \mathrm{CH}_{4}$ signature. This is also the case for natural gas which isotopic signature depends on the geological origin of the gas (e.g. Lopez et al, 2017).

\subsubsection{Keeling plot approach}

427

428

429

430

431

432

433

434

435

436

437

438

439

440

441

442

443

444

445

We used the Keeling plot method to infer the the $\delta^{13} \mathrm{CH}_{4}$ signature for each emission source (Keeling, 1958). This approach consists in plotting the atmospheric $\delta^{13} \mathrm{C}$ in $\mathrm{CH}_{4}$ values against the inverse of simultaneous atmospheric $\mathrm{CH}_{4}$ concentration data. The intercept value of the linear relationship between the two variables constitute the isotopic signature of the source which generated the methane signal over background (Pataki et al., 2003). The relative uncertainty of the source signatures were computed by the BCES (Bivariate Correlated Errors and intrinsic Scatter) estimator (Akritas and Bershady, 1996), which accounts for correlated errors between two variables and computes the error on the slope and intercept of the best interpolation line (for additional information on the method, see Zazzeri et al., 2015).

\section{3- Results}

\section{$3.1 \delta^{13} \mathrm{CH}_{4}$ signatures}

The $\mathrm{CH}_{4}$ maximum local concentration enhancement above background detected in the emission plume of each site and its isotopic signature are summarised in Table 5 . This enhancement is defined as the maximum minus the minimum concentrations that we measured by driving downwind of the site. In the following, all uncertainties are given as twice the standard deviation $(2-\sigma)$ of the mean source signature calculated by the Keeling Plot method.

\begin{tabular}{|c|c|c|c|c|c|c|}
\hline $\begin{array}{l}\text { Site } \\
\text { code }\end{array}$ & $\begin{array}{l}\text { Name (region, } \\
\text { department } \\
\text { code) }\end{array}$ & $\begin{array}{c}\text { Dates } \\
\text { of } \\
\text { survey }\end{array}$ & $\begin{array}{c}\text { Windspeed } \\
\text { in } \mathrm{km} / \mathrm{h} \\
\text { (direction) }\end{array}$ & $\begin{array}{l}\Delta \mathrm{CH}_{4} \\
(\mathrm{ppm})\end{array}$ & $\begin{array}{c}\delta^{13} \mathrm{C}\left({ }^{\circ} /^{\circ 0}\right) \\
\text { CRDS } \\
(2-\sigma) \\
\end{array}$ & $\begin{array}{c}\delta^{13} \mathrm{C}\left({ }^{\circ} /^{\circ}\right) \\
\text { GC-IRMS } \quad(2-\sigma)\end{array}$ \\
\hline \multicolumn{7}{|c|}{ Landfill sites } \\
\hline L1 & $\begin{array}{l}\text { Claye-Souilly } \\
\text { (IDF, 77) }\end{array}$ & $\begin{array}{r}11 \text { Aug } 2015 \\
9 \text { Dec } 2015 \\
\end{array}$ & $\begin{array}{l}<5(\mathrm{~N}) \\
5(\mathrm{SW})\end{array}$ & $\begin{array}{l}0 \\
1.4 \\
\end{array}$ & $\begin{array}{l}- \\
-\end{array}$ & $\begin{array}{c}- \\
-59.8 \pm 0.1\end{array}$ \\
\hline L2 & $\begin{array}{l}\text { Le Plessis- } \\
\text { Gassot } \\
\text { (IDF, 95) }\end{array}$ & $\begin{array}{l}19 \text { nov } 2015 \\
10 \text { Dec } 2015\end{array}$ & $\begin{array}{l}10(\mathrm{NW}) \\
10(\mathrm{~S})\end{array}$ & $\begin{array}{l}3.5 \\
3.8\end{array}$ & $\begin{array}{l}-53.0 \pm 2.0 \\
-59.4 \pm 2.0\end{array}$ & $\begin{array}{c}- \\
-58.2 \pm 0.3\end{array}$ \\
\hline L3 & $\begin{array}{l}\text { Vert-le-Grand } \\
\text { (IDF, 91) }\end{array}$ & $\begin{array}{l}18 \text { Nov } 2015 \\
8 \text { Dec } 2015\end{array}$ & $\begin{array}{l}15(\mathrm{SW}) \\
10(\mathrm{~S})\end{array}$ & $\begin{array}{l}3.5 \\
3.5\end{array}$ & $\begin{array}{l}-56.0 \pm 2.0 \\
\&-61.5 \pm 2.0 \\
-61.9 \pm 2.0\end{array}$ & $\begin{array}{c}- \\
-61.3 \pm 0.2\end{array}$ \\
\hline L4 & $\begin{array}{l}\text { Soignolles-en- } \\
\text { Brie (IDF, 78) }\end{array}$ & $\begin{array}{l}9 \text { Sept } 2015 \\
8 \text { Dec } 2015\end{array}$ & $\begin{array}{l}15(\mathrm{E}) \\
10(\mathrm{~S})\end{array}$ & $\begin{array}{l}2.8 \\
0.6\end{array}$ & - & $\begin{array}{c}- \\
-63.2 \pm 0.1\end{array}$ \\
\hline L5 & $\begin{array}{l}\text { Epinay- } \\
\text { Champlâtreux } \\
\text { (IDF, 95) closed } \\
31-12-08 . \\
\end{array}$ & 19 Nov 2015 & $5(\mathrm{NW})$ & 0 & - & - \\
\hline L6 & $\begin{array}{l}\text { Monthyon } \\
\text { (IDF, 77) }\end{array}$ & 19 Nov 2015 & $5(\mathrm{NW})$ & 0 & - & - \\
\hline
\end{tabular}




\begin{tabular}{|c|c|c|c|c|c|c|}
\hline L7 & $\begin{array}{l}\text { Fouju-Moisenay } \\
\text { - Blandy } \\
\text { (IDF, 77) }\end{array}$ & $\begin{array}{l}13 \text { May } 2014 \\
9 \text { Sep } 2015 \\
18 \text { Nov } 2015 \\
8 \text { Dec } 2015\end{array}$ & $\begin{array}{l}10(\mathrm{SW}) \\
15(\mathrm{E}) \\
10(\mathrm{NW}) \\
10(\mathrm{~S})\end{array}$ & $\begin{array}{l}3.5 \\
3.7 \\
3.2 \& 5.2 \\
3.5 \& 8.5\end{array}$ & $\begin{array}{l}-59.0 \pm 2.0 \\
-57.9 \pm 2.0 \\
-65.0 \pm 2.0 \\
-65.3 \pm 2.0 \\
\&-59.4 \pm 2.0\end{array}$ & $\begin{array}{c}- \\
- \\
- \\
-59.6 \pm 2.6\end{array}$ \\
\hline L8 & $\begin{array}{l}\text { Brueil-en-Vexin } \\
\text { (IDF, 78) from } \\
1974 \text { to } 24-02- \\
2014\end{array}$ & $\begin{array}{l}8 \text { Sep } 2015 \\
19 \text { Nov } 2015\end{array}$ & $\begin{array}{l}10 \text { (NE) } \\
10(\mathrm{NW})\end{array}$ & $\begin{array}{l}0 \\
0\end{array}$ & $\begin{array}{l}- \\
-\end{array}$ & $\begin{array}{l}- \\
-\end{array}$ \\
\hline L9 & $\begin{array}{l}\text { Isles-les- } \\
\text { Meldeuses } \\
\text { (IDF, 77) }\end{array}$ & $\begin{array}{l}8 \text { Sep } 2015 \\
9 \text { Dec } 2015\end{array}$ & $\begin{array}{l}10(\mathrm{NE}) \\
5(\mathrm{SW})\end{array}$ & $\begin{array}{l}3.5 \\
7.2\end{array}$ & $\begin{array}{l}-60.6 \pm 2.0 \\
-65.9 \pm 2.0\end{array}$ & $\begin{array}{c}- \\
-63.7 \pm 0.3\end{array}$ \\
\hline L10 & $\begin{array}{l}\text { Moisselles* } \\
\text { (IDF, 95) } \\
\text { Real place : } \\
\text { Attainville } \\
\end{array}$ & 19 nov 2015 & $5(\mathrm{NW})$ & 0 & - & - \\
\hline \multicolumn{7}{|c|}{ Gas storage sites } \\
\hline S1 & $\begin{array}{l}\text { Gournay-sur- } \\
\text { Aronde } \\
\text { (HDF, 60) }\end{array}$ & $\begin{array}{l}11 \text { Aug } 2015 \\
10 \text { Dec } 2015\end{array}$ & $\begin{array}{l}<5(\mathrm{~N}) \\
10(\mathrm{~S})\end{array}$ & $\begin{array}{l}8.1 \\
5.7\end{array}$ & $\begin{array}{l}-31.8 \pm 2.0 \\
-31.7 \pm 2.0\end{array}$ & $\begin{array}{c}- \\
-33.8 \pm 0.4\end{array}$ \\
\hline S2 & $\begin{array}{l}\text { Germigny-sous- } \\
\text { Coulombs (IDF, } \\
77 \text { ) }\end{array}$ & $\begin{array}{l}8 \text { Sep } 2015 \\
9 \text { Dec } 2015\end{array}$ & $\begin{array}{l}10(\mathrm{NE}) \\
5(\mathrm{SW})\end{array}$ & $\begin{array}{l}3.5 \\
0.6\end{array}$ & $\begin{array}{l}-40.4 \pm 2.0 \\
-\end{array}$ & $\begin{array}{c}- \\
-41.6 \pm 2.4\end{array}$ \\
\hline S3 & $\begin{array}{l}\text { Saint-Illiers-la- } \\
\text { ville (IDF, } 78 \text { ) }\end{array}$ & $\begin{array}{l}8 \text { Sep } 2015 \\
19 \text { Nov } 2015\end{array}$ & $\begin{array}{l}10 \text { (NE) } \\
10(\mathrm{NW})\end{array}$ & $\begin{array}{l}0 \\
0\end{array}$ & $\begin{array}{l}- \\
-\end{array}$ & $\begin{array}{l}- \\
-\end{array}$ \\
\hline S4 & $\begin{array}{l}\text { Beynes } \\
\text { (IDF, 78) }\end{array}$ & $\begin{array}{l}8 \text { Sep } 2015 \\
7 \text { Dec } 2015 \\
\end{array}$ & $\begin{array}{l}10 \text { (NE) } \\
<5 \text { (SE) }\end{array}$ & $\begin{array}{l}4.8 \\
3.5 \\
\end{array}$ & $\begin{array}{l}- \\
-45.8 \pm 2.0\end{array}$ & $\begin{array}{c}- \\
-43.4 \pm 0.5\end{array}$ \\
\hline S5 & $\begin{array}{l}\text { Saint-Clair-sur- } \\
\text { Epte (IDF, 95) }\end{array}$ & $\begin{array}{l}8 \text { Sept } 2015 \\
19 \text { Nov } 2015\end{array}$ & $\begin{array}{l}10(\mathrm{NE}) \\
10(\mathrm{NW}) \\
\end{array}$ & $\begin{array}{l}0 \\
0 \\
\end{array}$ & $\begin{array}{l}- \\
-\end{array}$ & - \\
\hline \multicolumn{7}{|c|}{ Gas distribution lines } \\
\hline G1 & BP (ring road) & 12 May 2014 & $10(\mathrm{SW})$ & $0.5-0.8$ & - & - \\
\hline G2 & $\begin{array}{l}\text { Paris city } \\
\text { districts }\end{array}$ & $\begin{array}{l}\text { 17-20 Dec } 2013 \\
12-15 \text { May } 2014 \\
11 \text { Aug } 2015 \\
20-23 \text { Nov } 2015\end{array}$ & $\begin{array}{l}10(\mathrm{SW}) \\
10(\mathrm{SW}) \\
<5(\mathrm{~N}) \\
10(\mathrm{~W})\end{array}$ & $\begin{array}{l}0-1.4 \\
0-2.0 \\
0-0.6 \\
0-0.5\end{array}$ & $\begin{array}{l}- \\
-39.1 \pm 2.0 \\
\&-41.8 \pm 2.0 \\
-\end{array}$ & $\begin{array}{l}- \\
- \\
-\end{array}$ \\
\hline G3 & Montrouge & 11 Aug 2015 & 5 (NE) & 0.7 & - & - \\
\hline \multicolumn{7}{|c|}{ Waste water treatment site } \\
\hline W1 & $\begin{array}{l}\text { Achères* } \\
\text { (IDF, 78) }\end{array}$ & $\begin{array}{l}17 \text { Dec. } 2012 \\
11 \text { Aug. } 2015 \\
10 \text { Dec. } 2015\end{array}$ & $\begin{array}{l}2(\mathrm{E}) \\
<5(\mathrm{~N}) \\
10(\mathrm{~S})\end{array}$ & $\begin{array}{l}4.0 \\
3.5 \\
0.4 \& \\
0.5\end{array}$ & $\begin{array}{l}-53.2 \pm 3.7 \\
-51.0 \pm 2.0 \\
-\end{array}$ & $\begin{array}{c}- \\
- \\
-51.9 \pm 0.2 \\
\&-55.3 \pm 0.1\end{array}$ \\
\hline $\begin{array}{l}\text { Table } \\
P I C A F \\
(K P) s \\
\text { precis } \\
\text { indica } \\
\mathrm{ACH}_{4} \\
\text { conce } \\
\text { signat }\end{array}$ & $\begin{array}{l}\text { Synthesis of our } \\
\text { is } \pm 5 \text { ppb }+0 \text {. } \\
\text { ce signature but } \\
\text { calculated from } \\
\text { in the correspor } \\
\text { calculated as } t \\
\text { tion measured } \\
\text { s could be measu }\end{array}$ & $\begin{array}{l}\text { results. The pre } \\
55 \% \text { of the meas } \\
\text { for one case not } \\
\text { the GC-IRMS } \\
\text { ding column. Tr } \\
\text { le difference be } \\
\text { ownwind of eac } \\
\text { ed, the } \mathrm{CH}_{4} \text { enh }\end{array}$ & $\begin{array}{l}\text { ision on } \\
\text { urement a } \\
d^{*} \text { for wh } \\
P \text { source } \\
\text { e local Ch } \\
\text { tween the } \\
\text { a site. Fo } \\
\text { ancement } i\end{array}$ & $\begin{array}{l}R D S \mathrm{CH}_{4} \\
d \pm 2.0 \% \\
\text { ch source } \\
\text { ignature } \\
4 \text { concen } \\
\text { maximur } \\
\text { cases w } \\
\text { calculate }\end{array}$ & $\begin{array}{l}\text { concentratio } \\
(2-\sigma) \text { on th } \\
\text { uncertainty is } \\
\text { yepends on } \\
\text { ation enhan } \\
\text { and the } r \\
\text { ere both } C / \\
\text { from GC da }\end{array}$ & $\begin{array}{l}\text { eported by } \\
\text { eeling plot } \\
3.7 \% \text {. The } \\
\text { ch site, as } \\
\text { nent noted } \\
\text { imum } \mathrm{CH}_{4} \\
S \text { and } \mathrm{GC}\end{array}$ \\
\hline
\end{tabular}

\subsection{Landfill sites}

Ten landfill sites were surveyed among which Claye-Souilly and Le Plessis-Gassot being by far two main landfills in IDF with emissions five to ten times larger than other 
landfills. Among those, only 6 of them were shown to emit plumes of methane that ranged from $0.8 \mathrm{ppm}$ to $8.5 \mathrm{ppm}$ above background concentrations recorded off site. No methane plume could be detected on 4 landfills : Epinay-Champlâtreux (site L5) and Brueil-en-Vexin (site L8), that were closed in 2008 and 2014 respectively, and Monthyon (site L6) and Moisselles (site L10, which is indeed located in Attainville). For Brueil-en-Vexin, Monthyon and Moisselles, the exposure of the instrumentation regarding these sites was not satisfying (instrumentation upwind of the site, or no road closer to the site than $1.5 \mathrm{~km}$ away, limiting the possibility to cross the site plume if any). For Epinay-Champlattreux, the wind exposure was satisfying as our instrumentation was close to the site and downwind of it. We can conclude that $1 /$ the Brueil-en-Vexin, Monthyon and Moisselles sites should be surveyed again with more favorable plume exposure conditions; and 2/ the Epinay-Champlâtreux site does not seem to emit methane, which can be explained by its closure several years ago in 2008.

The $\delta^{13} \mathrm{C}$ signatures of the methane plumes for the 6 landfills from which we were able to detect a methane plume could be characterized both by CRDS and GC-IRMS. The signatures otained by GC-IRMS range from $-63.7 \pm 0.3 \%$ o to $-58.2 \pm 0.3 \%$ o. The ones measured by CRDS span a range from $-65.9 \pm 2.0 \%$ to $-53.0 \pm 2.0 \%$. Both techniques give average signatures that are consistent within the error bars. These are typical from biogenic methane emissions and in agreement with the litterature (e.g. Lassey et al., 2011; Zazzeri et al., 2015). The mean signature calculated from CRDS data relies on 12 surveys on 4 sites, against 6 surveys on 6 sites for the one obtained from GC-IRMS data. 4 surveys were common to both methods on 4 different sites. On these 4 common sites the mean signature ( $\pm 2-\sigma$ variability) obtained from GC-IRMS measurements equals to $-60.7 \pm 4.7 \%$ o, which is very close to the mean signature calculated from CRDS data of $-61.7 \%$ ( $\pm 6.1 \%$ \%). The $2-\sigma$ variability of the measurements obtained by GC-IRMS is lower than by CRDS. This could come from differences in the two instrumental set-ups (flow rate of $25 \mathrm{~mL} / \mathrm{mn}$ by CRDS vs 5 $\mathrm{L} / \mathrm{mn}$ for the sampling bag set-up ; lengths of tubing of $10 \mathrm{~m}$ for CRDS, $2 \mathrm{~m}$ for bag sampler), a higher precision on the GC-IRMS measurements and a sampling time uncertainty estimated to be 5 seconds between the clocks of the two sampling systems.

4 of the 6 emitting sites were surveyed twice to five times with the Picarro analyzer, on different years and months and revealed a variability of the signature in the range of 5.2 to $7.0 \%$ per site $(2-\sigma)$. Indeed, several parameters control the isotopic signature of a landfill such as temperature, waste composition and how strong is the methane oxidation level due to methanotrophic bacteria in the top-soil cover (Zazzeri et al., 2015; Liptay et al., 1998). Changes in these parameters could explain the observed seasonal to annual variability of the $\delta^{13} \mathrm{C}$ signature of each landfill site. Note that the variability on one single landfill site can be higher than the spatial variability inferred by CRDS between these 4 sites $(6.2 \%$, $2-\sigma)$.

Claye-Souilly being the largest landfill emitter in the Airparif inventory (Table 1) was sampled twice. On the first survey (11 August 2015), no $\mathrm{CH}_{4}$ plume could be detected, although the car passed at the edge of the site downwind of it. Windspeed was low $(<5$ $\mathrm{km} \cdot \mathrm{h}^{-1}$ ), helping for the stay of the plume on the site, but the temperature at the moment of that survey in summer afternoon was relatively high $\left(>25^{\circ} \mathrm{C}\right)$, favouring the vertical dispersion of the plume by turbulence processes over the site. Back there in Dec. 2015, we could detect by CRDS a local methane concentration enhancement of $1.4 \mathrm{ppm}$ above background (Fig. 4 site L1) and measured a signature of $-59.8 \pm 0.1 \%$ by GC-IRMS (Fig.3a), typical of biogenic 
sources. The cold winter and low windspeed conditions $\left(<5 \mathrm{~km} \cdot \mathrm{h}^{-1}\right)$ favorized the accumulation of the plume at low altitudes over the site. The amplitude of the methane enhancement that we were able to detect on this site is relatively low compared to other sites and at such low windspeed.
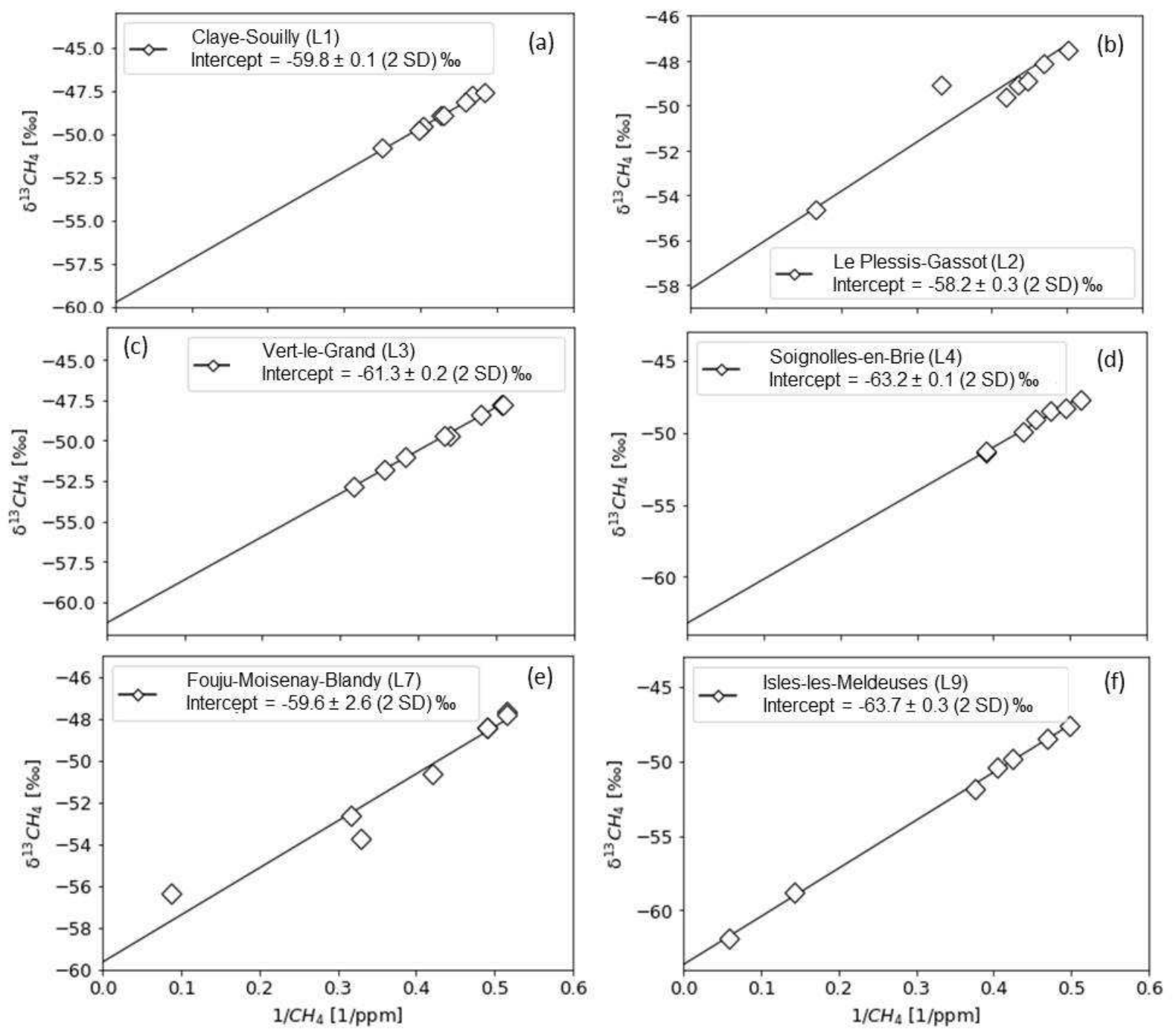

Figure 3. $\delta^{13} \mathrm{CH}_{4}$ signatures obtained by the Keeling plot method from GC-IRMS measurements on landfill sites on which methane plumes could be detected. Error bars are not shown as these are smaller than point marks.

The second largest site named Le Plessis-Gassot was sampled twice and showed local methane concentration enhancements above background of the order of $3.5 \mathrm{ppm}$. Fig. 4 (site L2) shows the CRDS measurements done on this site on 19 Nov. 2015, with a $\delta^{13} \mathrm{CH}_{4}$ signature of $-53.0 \pm 2.0 \%$. Both CRDS and GC-IRMS data were collected in Dec. 2015 and gave consistent isotopic signatures. The $\mathrm{p}$-value calculated on the $\mathrm{CH}_{4}$ concentration measurements made simultaneously by GC and CRDS is $0.23 \quad(n=14)$, showing no statistically significant difference between both datasets. Fig. $3 b$ shows the Keeling plot of the GC-IRMS signature. The plume sampled in Nov. 2015 was studied by CRDS only and the isotopic signature was $-53.0 \pm 2 \%$, which is notably above the Dec. 2015 values. This can be explained by the fact that the plume was not sampled at the same exact location and the wind was not exactly blowing from the same direction, highlighting the possibility of 
521 different isotopic signatures on large landfills that could come from the type of waste and/or 522 level of fermentation.
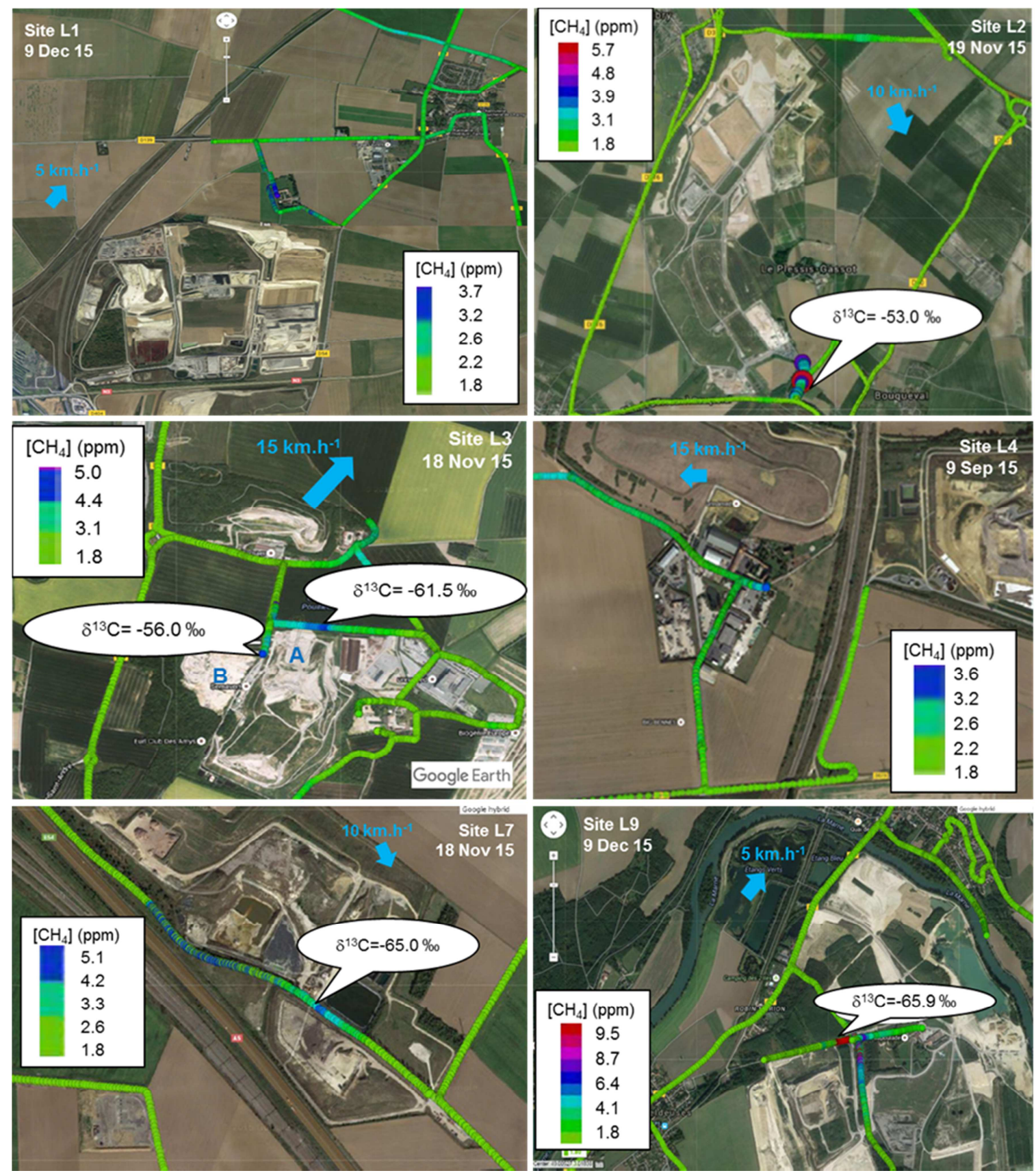

Figure 4. CRDS measurements on the 6 landfill sites on which methane plumes were detected. The date of the survey is labelled on the figure together with the site code. The color indicates the atmospheric $\mathrm{CH}_{4}$ concentration according to the color scale, which is automatically adapted to each survey by the Picarro investigator unit software. The $\delta^{13} \mathrm{CH}_{4}$ signature was inferred by Picarro from a Keeling plot analysis (uncertainty is $\pm 2.0 \%$ ). The blue arrow indicates the wind direction together with wind speed. For site $L 3$, the $A$ and $B$ letters indicate the possible locations of the two methane sources that were detected on that site that day.

Vert-le-grand ( $3^{\text {rd }}$ emitting landfill in Table 1, site L3) was sampled twice. In each case a methane plume with a local $\mathrm{CH}_{4}$ concentration enhancement of $3.5 \mathrm{ppm}$ above background 
was detected and with a signature of $-61.5 \pm 2.0 \%$ (18 Nov. 2015) and $-61.9 \pm 2.0 \%$ (8 Dec. 2015) by CRDS and $-61.3 \pm 0.2 \%$ by GC-IRMS (8 Dec. 2015) (Fig.3c). Although the CRDS and GC-IRMS methods give signatures that are very close one from each other, the p-value calculated on the $\mathrm{CH}_{4}$ concentration measurements made simultaneously by $\mathrm{GC}$ and CRDS is $0.019(n=16)$, which means there is likely a statistically significant difference between both datasets. In Nov 2015, a second plume could be detected by CRDS close to the first one with a signature of $-56.0 \pm 2.0 \%$ (Fig.4, site L3). Wind was blowing from the SW on 18 Nov.2015, while it was blowing from the $S$ on 8 Dec. 2015. In regards to this, the signature of $-61.5 \pm 2.0 \%$ (CRDS value) could be attributed to a source located in the A part of the site (Fig.4) while the $-56.0 \pm 2.0 \%$ signature (CRDS data) could be coming from a methane source located in the B part of the site (Fig.4). The two distinct signatures measured by CRDS on the same site highlight here as well the possibility of the co-existence of various biogenic signatures on a same site.

The Soignolles-en-Brie landfill, estimated to be the fourth landfill emitter (Table 1), was observed to emit a $\mathrm{CH}_{4}$ plume with a local methane concentration enhancement of 2.8 ppm above background in Sept. 2015 (Fig.4, site L4). A technical issue did not allow us to characterize the isotopic signature of this enhancement by CRDS. We went back to the site in Dec. 2015 and measured a local methane concentration enhancement of $0.8 \mathrm{ppm}$ above background and a source signature of $-63.2 \pm 0.1 \%$ by GC-IRMS, typical of biogenic methane emissions (Fig.3d). Note that additional surveys were carried out on this site in December 2016 with a CRDS analyzer by S. Assan et al. (https://tel.archives-ouvertes.fr/tel01760131/document), for which a signature of $-60.0 \pm 1.3 \%$ was reported with local enhancements ranging from 2 to $12 \mathrm{ppm}$ above background atmospheric methane concentration.

Fouju-Moisenay-Blandy showed the largest variability (but was the one the most sampled), with CRDS $\delta^{13} \mathrm{CH}_{4}$ signature values ranging from $-65.3 \pm 2.0 \%$ o to $-57.9 \pm 2.0 \%$ 。 and measured over 4 surveys between 13 May 2014 and 8 Dec. 2015. The CRDS measurements for 18 Nov. 2015 are shown on Fig. 4 (site L7), where a signature of $-65.0 \pm$ $2.0 \%$ was measured. On 8 Dec. 2015, two distinct plumes were detected by CRDS at this site with signatures of $-59.4 \pm 2.0 \%$ and $-65.3 \pm 2.0 \%$. The GC-IRMS signature equals $59.6 \pm 2.6 \%$ (Fig. $3 e$ ) and matches well the first CRDS plume signature, which corresponds to a local methane concentration enhancement of $8.5 \mathrm{ppm}$ above background, the largest one detected on this site, but also on all of the landfills that we surveyed in this study. The $p$ value computed on the corresponding $\mathrm{CH}_{4}$ concentration measurements made simultaneously by GC and CRDS is $0.024(n=16)$, revealing likely some statistically significant difference between the two datasets.

Isles-les-Meldeuses was sampled twice (Sept. and Dec. 2015) and was shown to produce a local methane concentration enhancement reaching $7.2 \mathrm{ppm}$ above background. The GC-IRMS mean signature measured in Dec.2015 (-63.7 $\pm 0.3 \%)$ is higher than that from CRDS $(-65.9 \pm 2.0 \%$ ) shown on Fig.4 (site L9), but both means superimpose within the measurements error bars. Indeed, the p-value of 0.145 obtained on these simultaneous CRDS and GC measurements does not reveal any statistically significant difference between the two datasets. Fig. $3 f$ shows the Keeling plot drawn from the GC-IRMS measurements. The CRDS signature measured in Sept. 2015 is notably higher $(-60.6 \pm 2.0 \%)$. The difference could be explained by the wind direction which was not the same, so that we did 
not sample exactly the same plume, highlithing here again the possible variability of the signature of one same site.

\subsection{Gas storage sites}

The five gas storages sites were surveyed twice, firstly in Summer 2015 and secondly in Winter 2015. On two of them (Saint-Illiers-la-Ville, S3, and Saint-Clair-sur-Epte, S5) we did not detect any local enhancement of the methane concentration. At Saint-Clair-sur-Epte during both surveys the car passed at least $450 \mathrm{~m}$ away downwind of the site and could not get closer to it. This could explain why we did not detect any methane plume there, but there is a possibility too that the site does not emit any methane plume at all. At Saint-Illiers-laVille, the car passed at different places within the site and was well exposed downind of it. Therefore, it seems very likely that this site does not leak methane to the atmosphere.
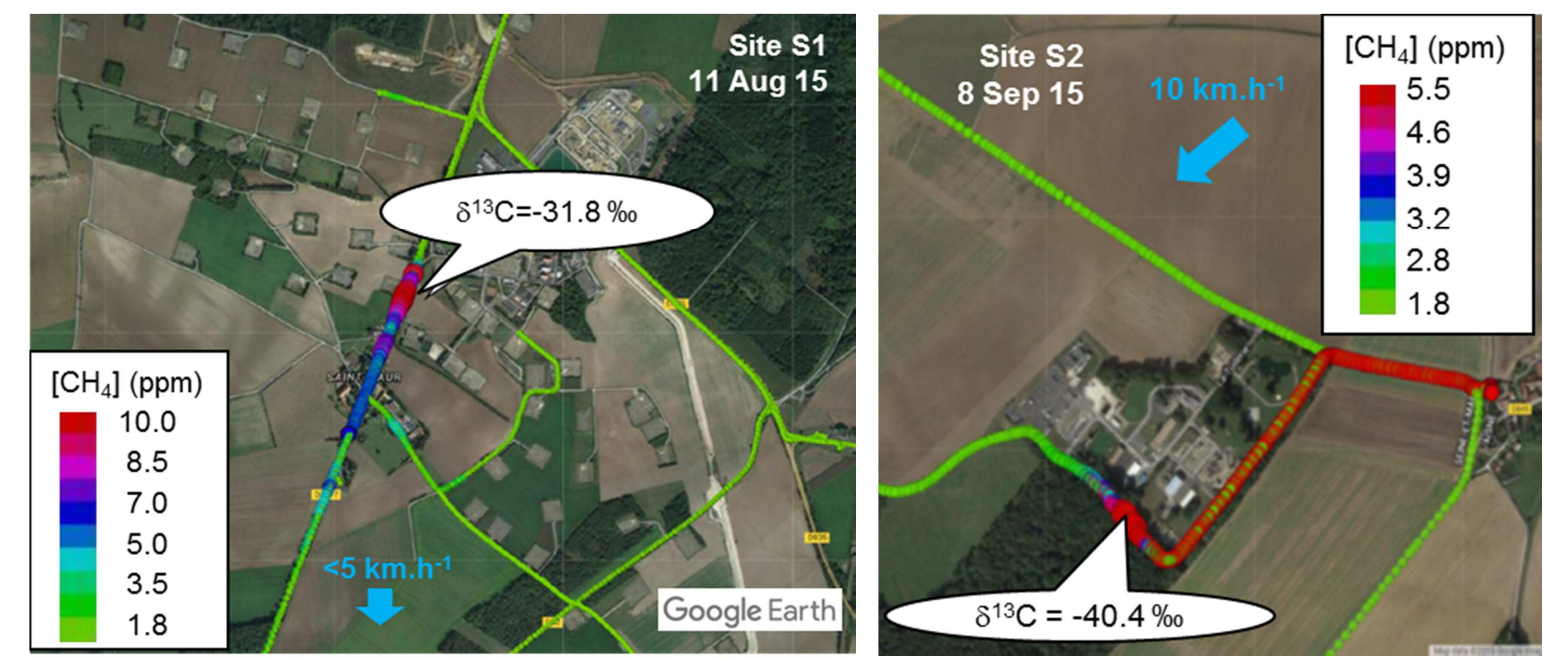

Figure 5. Left : Methane concentration measured by CRDS on 11 Aug. 2015 at Gournay-surAronde (site S5) showing a local methane enhancement of $8.1 \mathrm{ppm}$ above background concentration with a $\delta^{13} \mathrm{CH}_{4}$ signature of $-31.8 \pm 2.0 \%$. Right : Same but at Germigny-sousCoulombs on 8 September 2015 at Germigny-sous-Colombs (site S2) showing a local methane enhancement of $3.5 \mathrm{ppm}$ above background with a $\delta^{13} \mathrm{CH}_{4}$ signature of $-40.4 \pm 2.0$ \% (CRDS, 8 September 2015). The blue arrow and label indicate wind direction and speed. The color scale is automatically adapted to each survey by the Picarro investigator unit software.

The three other sites (Gournay-sur-Aronde, S1, Germigny-sous-Coulomb, S2, and Beynes, S4) emitted methane plumes with local $\mathrm{CH}_{4}$ concentration enhancements ranging from $0.6 \mathrm{ppm}$ to $8.1 \mathrm{ppm}$ over background concentrations. The $\delta^{13} \mathrm{CH}_{4}$ signature of the methane plumes detected on the three leaking gas storages sites are highly variable. The signature obtained from the CRDS data ranges from $-45.8 \pm 2.0 \%$ o to $-31.7 \pm 2.0 \%$. Using GC-IRMS data, it ranges from $-43.4 \pm 0.5 \%$ o to $-33.8 \pm 0.4 \%$ o depending on the site and on the period but all stay within the expected range for natural gas of $-50 \%$ o to $-30 \%$ as given by the literature (e.g. Dlugokencky et al., 2011 ; Zazzeri et al., 2015 ; Sherwood et al., 2016).

Among the gas storage sites, the highest concentration was measured by CRDS on the Gournay-sur-Aronde on 10 August 2015, leading to an enhancement of $8.1 \mathrm{ppm}$ above 
background with a signature of $-31.8 \pm 2.0 \%$ (Fig. 5, site S1). According to the Airparif 2013 emissions inventory, Gournay-sur-Aronde is the most emitting gas storage site of IDF (Table 2). This site was sampled once again on 10 Dec. 2015 with local methane concentration enhancements higher than $1.5 \mathrm{ppm}$ above background, allowing us to measure the $\delta^{13} \mathrm{CH}_{4}$ signature of the methane plume by CRDS during both surveys. The CRDS signature is consistent for both measurements $(-31.7 \pm 2.0 \%$ and $-31.8 \pm 2.0 \%$ o). Bag samples were also taken and analyzed by GC-IRMS on 10 December 2015, which gave a $\delta^{13} \mathrm{CH}_{4}$ signature of $-33.8 \pm 0.4 \%$, at the lowest edge of the CRDS error bar (Fig. 6a). The p-value computed on the $\mathrm{CH}_{4}$ concentration simultaneous measurements made by GC and CRDS is 0.046 $(n=10)$, revealing likely some statistically significant difference between the two datasets.
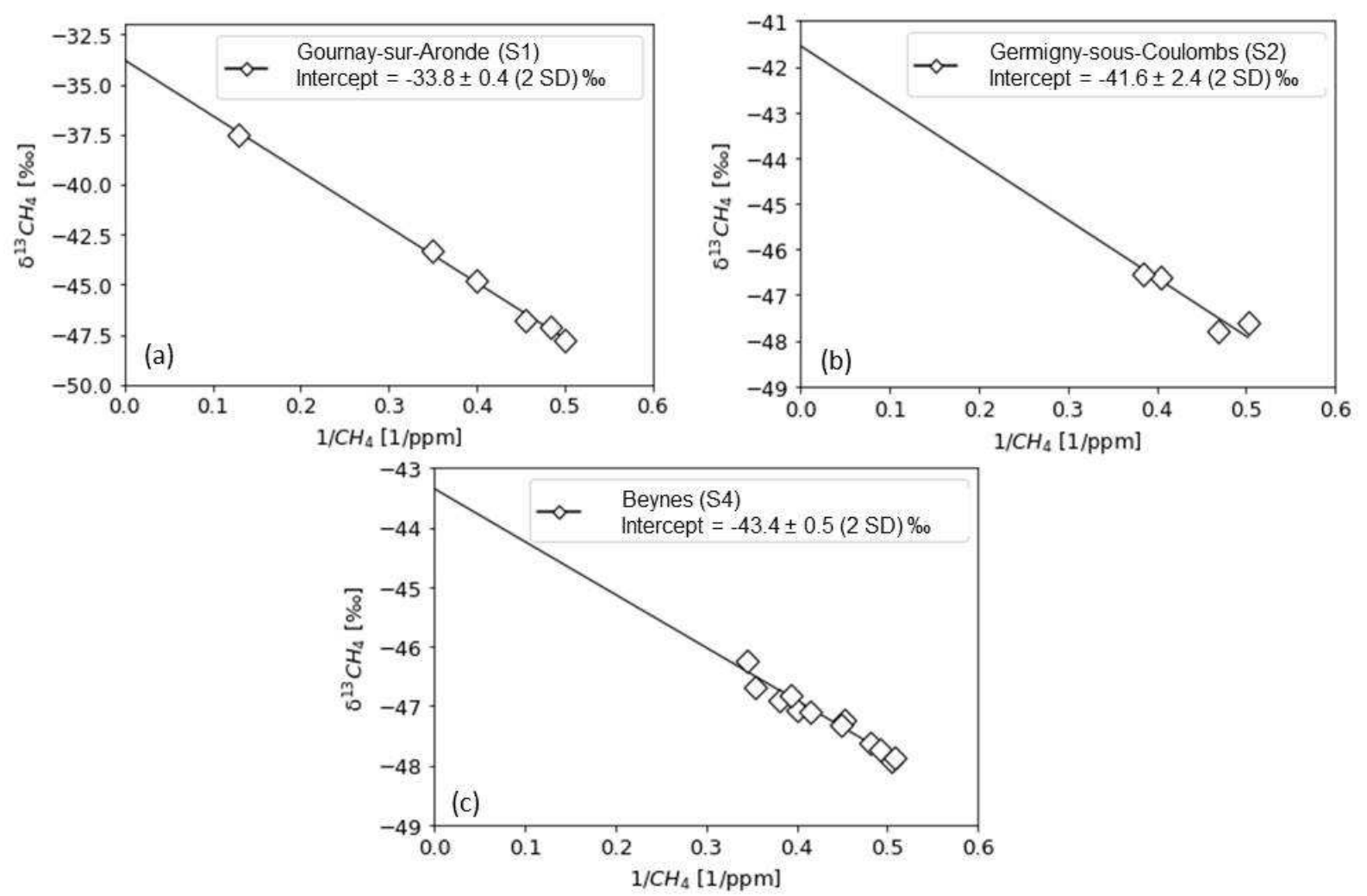

Figure 6. $\delta^{13} \mathrm{CH}_{4}$ signatures obtained by the Keeling plot method from GC-IRMS measurements on gas storage sites on which methane plumes could be detected. Error bars are not shown as these are smaller than point marks.

The Germigny-sous-Coulombs site (S2) is the second most emitting gas storage site in the Airparif inventory (Table 2). We measured plumes with local $\mathrm{CH}_{4}$ enhancements ranging from 0.6 to $3.5 \mathrm{ppm}$ above background. CRDS measurements gave a $\delta^{13} \mathrm{CH}_{4}$ signature of $-40.4 \pm 2.0 \%$ in September 2015 (Fig. 5, site S2), and GC-IRMS measurements provided in December 2015 a source signature of $-41.6 \pm 2.4 \%$ (Fig. 6b). The main leaks were mostly detected along the road (likely from underground pipelines) northeast of the site (Fig. 5, site S2). These values are lower of several \%o than the signature of the methane plume detected on the Gournay-sur-Aronde site (see section 4.2).

The last gas storage site on which a $\mathrm{CH}_{4}$ plume could be detected was Beynes (S4), with local methane concentration enhancements ranging between 1.5 and 4.8 ppm above 
background (Fig. 7). The $\delta^{13} \mathrm{CH}_{4}$ signature of the plume was measured on 7 December 2015 both by CRDS ( $45.8 \pm 2.0 \%$ ) and by GC-IRMS (-43.4 $\pm 0.6 \%$ ) (Fig. 6c). Opposite to the two other leaking gas storage sites, the GC-IRMS signature is here higher than the CRDS one and out of the upper edge of the CRDS measurement error bar. The p-value calculated on these $\mathrm{CH}_{4}$ concentration measurements made simultaneously by GC and CRDS is 0.003 $(n=24)$, revealing likely a statistically significant difference between both datasets. Unfortunately, a technical problem did not allow us to characterize the plume signature by CRDS on 8 September 2015 survey. The existence of a possible bias due to ethane coemitted with methane in the CRDS $\delta^{13} \mathrm{CH}_{4}$ signature calculation is evaluated in Section 4. According to the wind direction, the two surveys show that the methane plume are likely emitted from the surface facilities of the site (zone A on Fig. 7) rather than from the wheels (zones B and B' on Fig. 7) that are connected to the 2 deep aquifer storages of natural gas of this site (https://www.storengy.com/countries/france/images/ contenuFR/nos_sites/ stockage_en_nappe_aquifere.jpg).
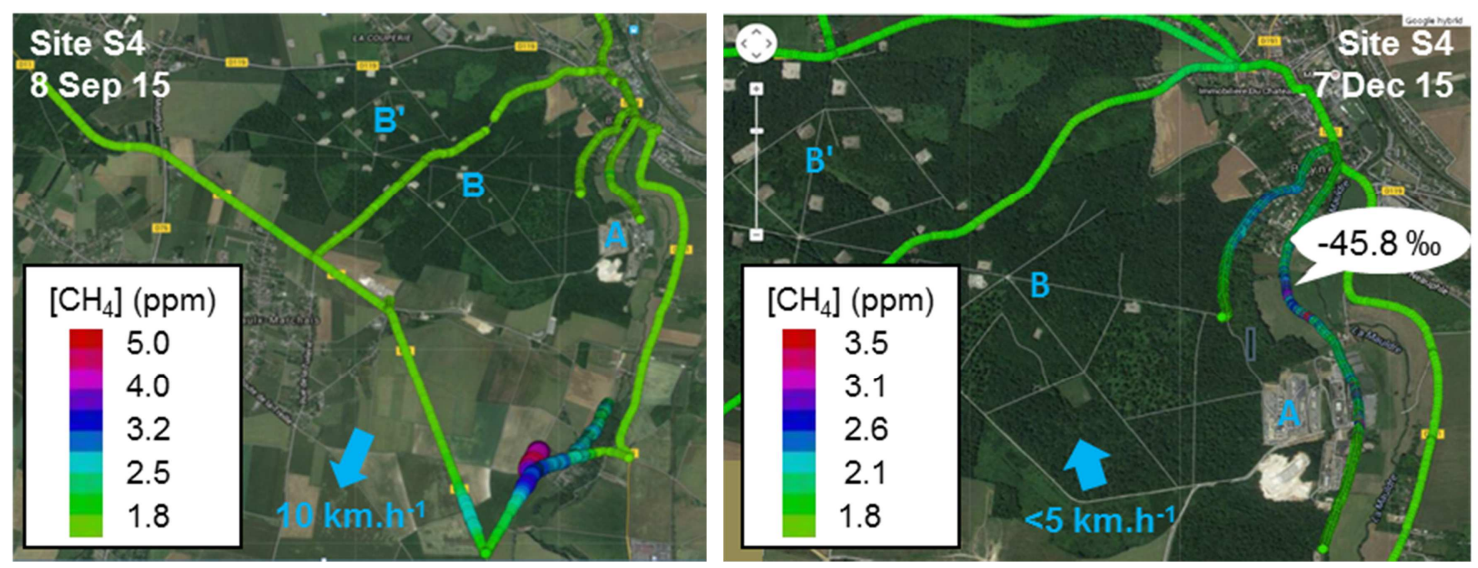

Figure 7. Methane concentration measured by CRDS at Beynes (S4) on 8 Sept. 2015 (left) and 7 Dec. 2015 (right) revealing local $\mathrm{CH}_{4}$ enhancements. On the second survey the signature of the enhancement was characterized as $-45.8 \pm 2.0 \%$ by CRDS and $-43.4 \pm 0.5$ $\%$ by GC-IRMS. Unfortunately the signature was not characterized on 8 Sept. 2015. The blue arrow and label indicate wind direction and speed. The A letter indicates the location of the surface facilities of the site (compressors, pumps, pipelines...). The $B$ and $B$ ' letters indicate the location of wheels connected to two deep aquifer storages of natural gas. The color scale is automatically adapted to each survey by the Picarro investigator unit software.

\subsection{Gas distribution network of Paris}

About 1000 kilometers were driven to survey the streets of Paris and surrounding suburbs (Fig. 8, Table 3). No methane plume was detected on the Paris ring road but one at Porte d'Orléans (south of Paris) with a local $\mathrm{CH}_{4}$ enhancement of $\sim 0.7 \mathrm{ppm}$ above background. Furthermore, more than forty local $\mathrm{CH}_{4}$ enhancements were detected in streets of Paris. In two places in the Northern districts of Paris (Fig. 8b) the local methane concentration enhancements were strong enough (3.5 and $3.9 \mathrm{ppm}$ above background to characterize their isotopic signatures by CRDS $(-39.1 \pm 2.0 \%$ ond $-41.8 \pm 2.0 \%$ o). 

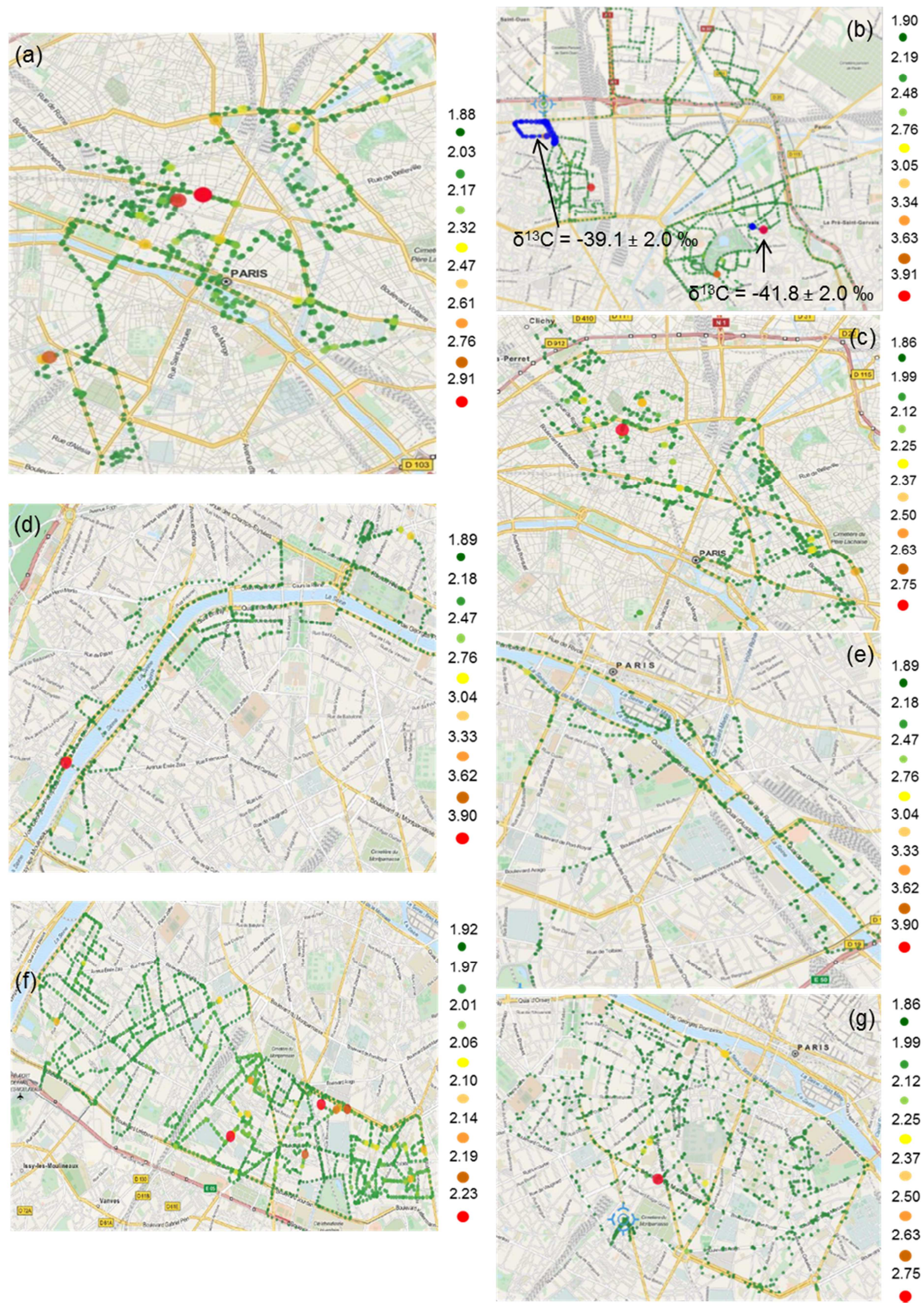

Figure 8. Picarro CRDS atmospheric methane concentration measurements in the districts of the Paris city (site G2) performed between December 2013 and November 2.015 (colored points indicate the atmospheric $\mathrm{CH}_{4}$ concentration according to the color scale in ppm, that is adapted automatically to each survey by the Picarro investigator unit software) - (a) mostly 
Paris $1^{\text {st }}, 2^{\text {nd }}, 3^{\text {rd }}, 4^{\text {th }}, 6^{\text {th }}, 7^{\text {th }}, 8^{\text {th }}, 9^{\text {th }}$ and $10^{\text {th }}$ districts ; (b) North of the center of Paris (mostly $18^{\text {th }}, 19^{\text {th }}$ and $20^{\text {th }}$ districts) with CRDS isotopic signatures of the detected leaks - (c) Paris $11^{\text {th }}$ to $17^{\text {th }}$ districts survey - (d) and (e) along the Seine river - (f) Paris $13^{\text {th }}, 14^{\text {th }}$ and $15^{\text {th }}$ districts. Blue dots represent periods of measurement interruption due to isotopic analysis.

These values are close to the value measured on the gas storage of Germigny-sousCoulombs and are typical of thermogenic methane. Here we can exclude a biogenic origin of methane and therefore emanations from the sewer networks. We can clearly attribute these signatures to natural gas, proving the existence of leaks on the gas pipelines of the Paris network. In about 40 other places, very local methane concentration enhancements were also found but they were too small for CRDS isotopic analysis $(<3.5 \mathrm{ppm})$ and they would have required bag sampling to distinguish leaks from the natural gas network or emanations from sewage facilities.

\subsection{Waste water treatment site}
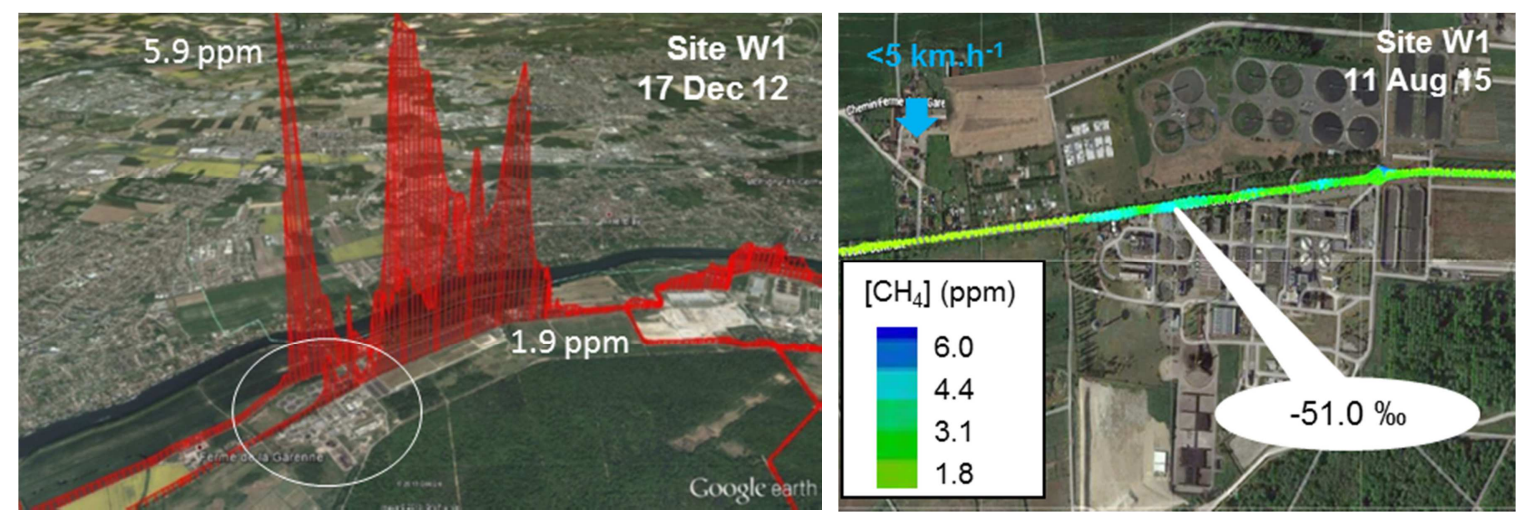

Figure 9. Left : Google Eath view of methane plumes detected by CRDS on the Achères WWT facility on 17 Dec. 2012 (site W1) revealing several local methane concentration enhancements above background (background concentration is 1.9 ppb and maximum concentration is $5.9 \mathrm{ppm})$. The white ellipse indicates the location of the right figure. Right : methane concentration measured on the same site (white ellipse on the left figure) by CRDS on 11 Aug. 2015 showing a methane enhancement of 3.5 ppm above background and $\delta^{13} \mathrm{CH}_{4}$ signature of $-51.0 \pm 2.0 \%$. The blue arrow indicates wind direction together with windspeed. The color scale is automatically adapted by the Picarro investigator unit software.

The Achères WWT facility (site W1) was first surveyed by the Picarro mobile unit on 17 December 2012 (Fig. 9). Both weak wind conditions (wind speed $\sim 2 \mathrm{~km} \cdot \mathrm{h}^{-1}$ ) and cold temperatures $\left(\sim 5^{\circ} \mathrm{C}\right)$ favorized the accumulation of the methane plume on the site. The background concentration is in the range of $1.9 \mathrm{ppm}$ and the maximum concentrations reach $5.9 \mathrm{ppm}$. A local $\mathrm{CH}_{4}$ methane concentration enhancement of $4.0 \mathrm{ppm}$ above background was detected on this site, as in Ars (2017) with a $\delta^{13} \mathrm{CH}_{4}$ signature of $-53.2 \pm 3.7 \%$ on that day. The same plume was detected again on 10 August 2015 and 10 December 2015 with enhancements of $3.5 \mathrm{ppm}$ (windspeed $<5 \mathrm{~km} \cdot \mathrm{h}^{-1}$ ) and $0.4 \mathrm{ppm}$ (windspeed $10 \mathrm{~km} \cdot \mathrm{h}^{-1}$ ), respectively, and a signature of $-51.0 \pm 2.0 \%$ (CRDS) and $-51.9 \pm 0.2(2-\sigma) \%$ (GC-IRMS) (Fig. 10), respectively.

A second plume (Fig. 10) with a different isotopic signature was detected on 10 December 2015 with a local methane concentration enhancement of $0.4 \mathrm{ppm}$ above 
background (windspeed $\sim 10 \mathrm{~km} \cdot \mathrm{h}^{-1}$ ) and a signature of $-55.3 \pm 0.1(2-\sigma) \%$ (GC-IRMS). All these isotopic hese values are typical of biogenic sources. We note here that the lower the windspeed is, the higher the methane enhancement is, as the car was able to pass at the edges of the site and could easily catch the methane plumes.

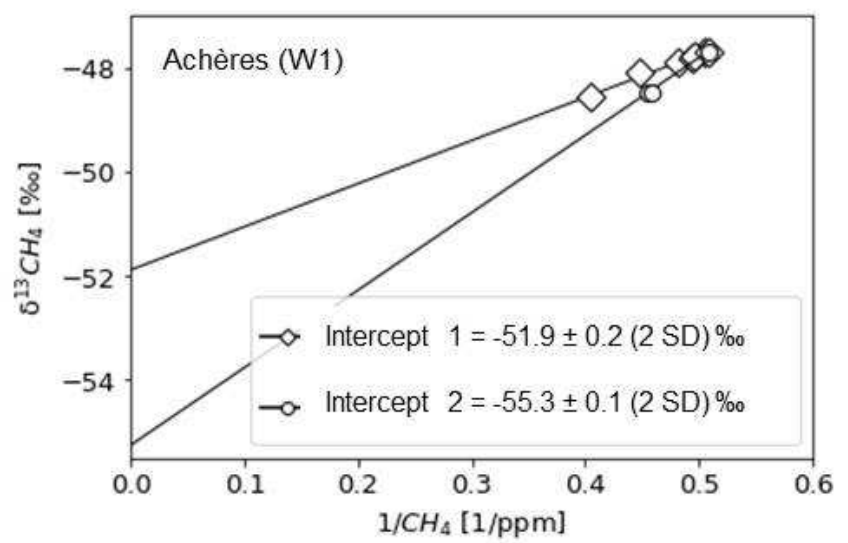

Figure 10. $\delta^{13} \mathrm{CH}_{4}$ signatures obtained by the Keeling plot method from GC-IRMS measurements on the Achères WWT site (W1) on 10 December 2015. Two plumes could be identified, both with a $\delta^{13} \mathrm{CH}_{4}$ signature typical of biogenic sources. Error bars are not shown as these are smaller than point marks.

\section{4- Discussion and conclusions}

\subsection{Overview}

Fig. 11 synthesises the local $\mathrm{CH}_{4}$ concentration enhancements that we measured and their $\delta^{13} \mathrm{CH}_{4}$ signatures on the landfills, gas storages, gas lines and WWT facility in the Paris megacity region that we characterized for the first time, by CRDS and/or by GC-IRMS. Overall, methane plumes could be detected on 6 over 10 landfills surveyed, 3 over 5 gas storage sites studied and on the surveyed WWT facility. About forty local $\mathrm{CH}_{4}$ enhancements were also found in streets of Paris city as well as in Montrouge in the South-West surburbs of Paris, and on the Boulevard Périphérique : using CRDS we could assign a $\delta^{13} \mathrm{CH}_{4}$ signature typical of natural gas to 2 of them, but we did not have the fundings to characterize the precise signature of all of them by GC-IRMS. Very likely, these 2 enhancements come from leaks on the pipelines of the Paris natural gas distribution network.

\subsection{Comparison of CRDS and GC-IRMS results}

The studies of Rella et al. (2015) and Assan et al. (2017) demonstrated the importance of a careful determination of cross sensitivities and a good calibration strategy for precise isotope measurements with a CRDS analyzer. A few recent studies reported that the methane concentration measured by PICARRO CRDS analyzers could be biased by the presence of ethane with methane (e.g. Rella et al., 2015; Assan et al., 2017; Lopez et al., 2017). This bias would generate an error on the determination of the $\delta^{13} \mathrm{CH}_{4}$ signature of sources. It is difficult to make a comparison of the concentrations measured directly by CRDS and the concentrations of the samples collected at the same time measured in 
laboratory, because the bag sampling took about 30 seconds of sampling, atmospheric concentration enhancements within the plume were often highly variable and we could not measure that time with a precision higher than several seconds. We thus compared the $\delta^{13} \mathrm{CH}_{4}$ signatures obtained from the CRDS and GC-IRMS measurements, which represent the main focus of this study, but not the values of the $\mathrm{CH}_{4}$ enhancements obtained by both technics, as the precise quantification of these enhancements is not the aim of our study as mentioned earlier. Fig.12 synthesises the $\delta^{13} \mathrm{CH}_{4}$ signatures measured by CRDS and GCIRMS, which we can use to assess any error in the CRDS measurements, taking the GCIRMS signature as a reference. We compare here only the 6 cases when both CRDS and GC-IRMS samples were taken simultaneously, indicated by black-framed markers on Fig.12.

Atmospheric ethane sources are mostly fossil fuels, biomass burning and biogas (e.g. Assan et al., 2017). There is no ethane source known from landfills. An additional survey in 2016 in Soignolles-en-Brie revealed no ethane source on that landfill (F. Vogel, personal communication), supporting this hypothesis. For this type of sites, the CRDS minus GCIRMS $\delta^{13} \mathrm{CH}_{4}$ signature difference ranges from -0.2 to $2.3 \%$ o with a mean value of $1.0 \pm 2.2$ $\% \circ(2-\sigma)$. The mean difference and its standard deviation are higher than the GC-IRMS data mean uncertainty $(0.85 \%$ ) but stay close to the CRDS mean uncertainty $(2.0 \%$ ). While for two landfill sites (Le Plessis-Gassot and Isles-les-Meldeuses) no statistically significant difference was found, for two others (Fouju-Moisenay and Vert-le-Grand), the p-values calculated from the methane concentration simultaneous measurements made by CRDS and bag sampling / GC analysis indicate likely a statistically significant difference between both datasets, although both match within the CRDS error bars. This difference could be explained by the much higher precision and accuracy of the GC dataset.

Conversely to landfills, methane leaks in gas storage sites are found together with ethane leaks, as natural gas is one of the main natural biogenic sources of ethane (Assan et al., 2017). On these sites, the CRDS - GC-IRMS difference ranges from -2.1 to $2.5 \%$ with a mean difference of $-0.7 \pm 4.2(2-\sigma)$. The standard deviation of the mean is higher than the CRDS and GC-IRMS data uncertainties $(2.0 \%$ and $1.13 \%$, respectively) and this could be explained by ethane - methane cross-sensitivity in the CRDS analyzer (but no ethane data were available to verify this hypothesis). On both gas storage sites where CRDS measurements and bag samples / GC analysis were performed, the p-values indicate likely a statistically significant difference between both datasets, which could be due to the presence of ethane, but also to the higher precision/accuracy of the GC dataset. For the WWT site, there was no simultaneous CRDS and GC - IRMS results. However, WWT facilities are not known to be ethane sources.

For the gas storage sites, we thus recommend not to use the $\delta^{13} \mathrm{CH}_{4}$ signature obtained by CRDS measurements but rather the GC - IRMS ones, as some bias larger than the instrumental uncertainty could explain the CRDS - GC-IRMS differences observed here, which might depend on the amount of ethane content into each methane plume. The landfills and the WWT plant signatures do not overlap with the gas storage sites ones. Overall, the mean signature of both source types can be disentangled by GC- IRMS and even by CRDS. But in two cases (L2 and L3 sites in Nov. 2015), the individual signatures obtained by CRDS for landfills overlap the WWT facility signature measured by GC-IRMS and CRDS. We therefore recommend to better use GC -IRMS also for landfills and WWT facilities, which provides more precise measurements than the CRDS ones. It would be also interesting to go 

observed on these sites, as discussed further below.

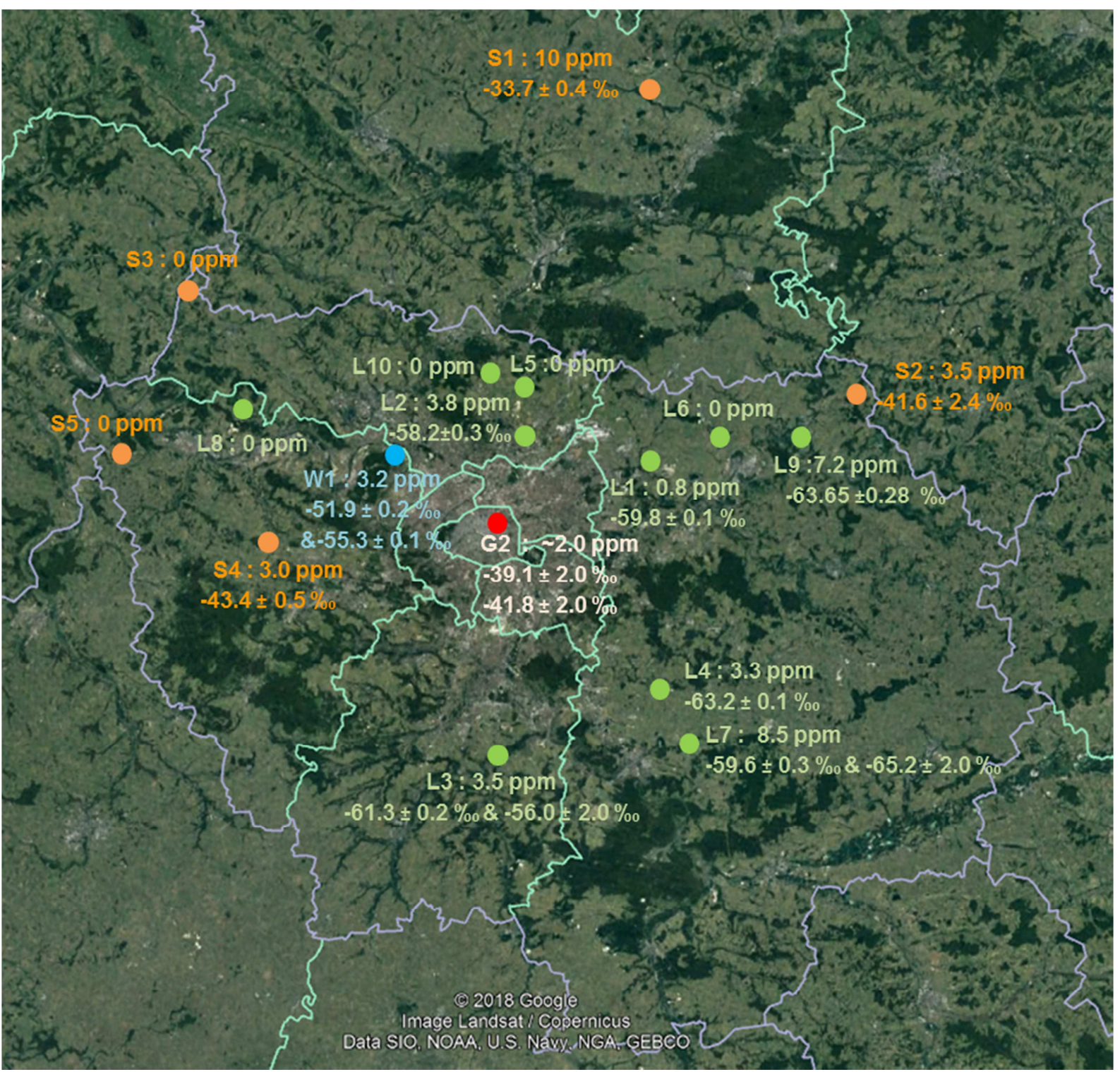

Figure 11. Synthesis of our results showing the maximum of methane concentration enhancements measured in the local plumes (in ppm above background) and their $\delta^{13} \mathrm{CH}_{4}$ signature (in \%o) on the sites surveyed in this study. Sites code are the following; Landfills : $L 1=$ Claye-Souilly, $L 2=$ Le Plessis-Gassot, L3 = Vert-le-Grand, L4=Soignolles-en-Brie, $L 5=$ Epinay-Champlâtreux, $L 6=$ Monthyon, $L 7=$ Fouju-Moisenay-Blandy, $L 8=$ Brueil-enVexin, $L 9$ = Isles-les-Meldeuses, $L 10$ = Moisselles - Attainville; Gas storage sites : $S 1$ = Gournay-surAronde, S2 = Germigny-sous-Coulombs, S3 = Saint-Clair-sur-Epte, S4 = Beynes, S5 = Saint-Illiers-la-Ville ; WWT facility : W1 = Achères ; and Paris streets : G2. 


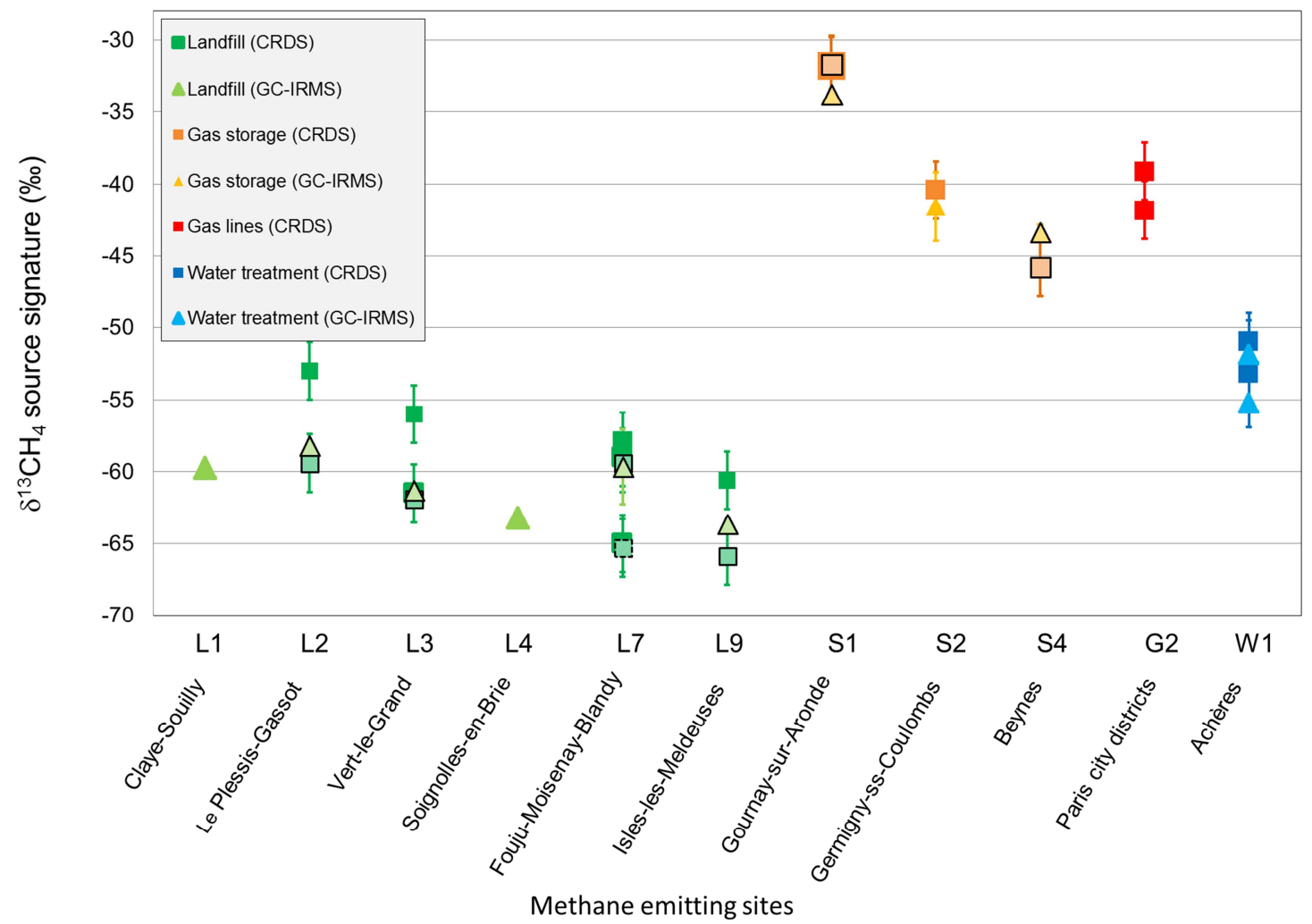

Figure 12. Synthesis of the $\delta^{13} \mathrm{CH}_{4}$ signatures of the plumes emitted by several landfills, gas storages, gas lines and WWT sites of the Paris megacity region and measured by CRDS and GC-IRMS technics. The CRDS and GC-IRMS results obtained on the same date are indicated by black-framed markers. One specific point indicated with a dashed-line frame corresponds to a second plume detected on $L 7$ site by CRDS on the same day that the joined CRDS - GC-IRMS measurements. The error bars are given according to Table 5. Error bars for sites $L 1$ and $L 4$ are smaller than the mark size.

\subsection{Source attribution}

Regarding landfills, the GC-IRMS mean signature that we measured $(-61.0 \pm 2.2 \%$ o) show some variability which is partly due to landfill emissions seasonal variability (Börjesson et al., 2001) that relies on several parameters : temperature, the waste composition and the strength of the methane oxidation level due to methanotrophic bacteria in the top-soil cover : methanotrophic bacteria in the upper soil layers, under aerobic conditions, mineralize methane to $\mathrm{CO}_{2}$, leaving the residual methane that diffuses through the soil cover relatively ${ }^{13} \mathrm{C}$ enriched, as methanothrophs use preferentially the lighter isotope (Zazzeri et al., 2015 ; Liptay et al., 1998). Zazzeri et al. (2015) reported a signature of $-58 \pm 3 \%$ (2- $\sigma)$ for waste disposal and landfills in SE England. Bergamaschi et al. (1998b) reported for German and Dutch landfill signatures ranging between $-59.0 \pm 2.2 \%$ o and $-45.9 \pm 8.0 \%$ (where the most enriched signature was attributed to the activity of methanotrophic bacteria). Phillips et al. (2013) reported signatures of $-57.8 \pm 1.6 \%$ for landfills in the Boston area. Our results are close to the values reported by Zazzeri et al. (2015), Phillips et al. (2013) and also by Bergamaschi et al. (1998b) in no presence of methanotrophic bacteria. Following this first study, more surveys are needed to assess the seasonal variability of the sources, and 
topsoil oxidation that drives heavier the isotopic signature of residual emitted methane is no longer a significant source in NW Europe (D. Lowry, personal communication).

The largest variability in the $\delta^{13} \mathrm{CH}_{4}$ signature is observed on the gas storage sites. Our dataset do not allow us to assess the temporal variability of the $\delta^{13} \mathrm{CH}_{4}$ signature on each gas storage site. By computing a mean signature including the GC-IRMS values for the sites S1, S2 and S4, we obtain a mean signature and its associated 2- $\sigma$ variability of $-39.6 \pm$ $10.2 \%$ (2- $\sigma)$. The CRDS mean signature and its associated $2-\sigma$ variability are $-38.4 \pm 11.2 \%$ 。 $(2-\sigma)$. While our mean value is close to the one of $-39.1 \pm 1.1 \%$ reported for the natural gas signature in Paris by Widory and Javoy (2003), it is characterized by a large variability between the sites and possibly the temporal variability at each site. This variability can be explained by the geological origin of the natural gas. According to SEDS (2018), natural gas is delivered to France by Norway (40\%), Russia (26\%) followed by the Netherlands (11\%), Algeria (9\%) and a few other countries. Gas from Norway and the North Sea has a reported signature spanning a large range from $-43.9 \%$ (Sherwood et al., 2016) to -24\%o (Zazzeri et al., 2015) and typically around $-35 \%$ (Dlugokencky et al., 2011). Natural gas from Russia is more ${ }^{13} \mathrm{C}$ depleted with a signature that can reach $-50 \%$ (Dlugokencky et al., 2011), and reported as $-46.4 \%$ by Sherwood et al. (2016). Natural gas from the Netherlands has a more ${ }^{13} \mathrm{C}$ enriched signature ranging from $-32.8 \%$ (Sherwood et al., 2016) to $-29.5 \pm 0.1 \%$ (Zazzeri et al., 2015). Eventually, natural gas from Nigeria is reported with a $\delta^{13} \mathrm{CH}_{4}$ signature of $-43.1 \%$ (Sherwood et al., 2016).

The gas storages sites that we surveyed are distributed among 3 zones defined by the gas exploitation company Storengy (https://www.cre.fr/Gaz-naturel/Reseaux-de-gaznaturel/Presentation-des-reseaux-de-gaz-naturel). The natural gas sampled in the Gournaysur-Aronde site has the heaviest $\delta^{13} \mathrm{CH}_{4}$ signature $(-33.7 \pm 0.44 \%$ ) of the 3 emitting gas storages sites surveyed in this study. Its $\delta^{13} \mathrm{CH}_{4}$ signature is indeed typical of thermogenic gas coming from the Netherlands and the North Sea. According to STORENGY (https://www.storengy.com/countries/france/fr/nos-sites/gournay-sur-aronde.html), this site is the only one in France is supplied by the Netherlands. Therefore, according to our results, this information pushes for attributing from this study a signature of $-33.7 \pm 0.4 \%$ o to Dutch gas ; but this possible attribution should be confronted with further investigation on the Dutch gas signature. Gournay-sur-Aronde is part of the north zone called "Sediane B " by Storengy and is effectively on the path of the main gas line of the North of France that receives gas from the Netherlands. Natural gas in Germigny-sous-Coulombs and in Beynes is more ${ }^{13} \mathrm{C}$ depleted $(-41.6 \pm 2.4 \%$ and $-43.4 \pm 0.5 \%$, respectively). Germigny-sousCoulombs is part of the so-called STORENGY "Serène Nord 》 north-east zone, which is connected to gas lines from Russia; therefore this source of methane could be attributed to Russian gas. Beynes is part of the north-west "Sediane » north-west zone of STORENGY which is connected both to the gaselines from Russia and to the methane terminal of Montoir-sur-Bretagne, where natural gas from Nigeria and other African countries is shipped to France; the signature of this site can likely be attributed to Russian gas or less likely to Nigerian gas. However, although we provide the most probable picture of the natural gas distribution network, STORENGY does not clearly indicate the gas origin for the Beynes and Germigny-sous-Coulombs sites. As these sites are interconnected to all the gaslines network of the north of France, their isotopic signature could either be attributed to gas from Norway, North Sea, Russia or African sources, which signature is not unique and could match with our measurements. Furthermore, the isotopic signature of sources can change with season 
(e.g. Zazzeri et al., 2015), as well as the source itself. Therefore, further surveys are needed to assess the seasonal variability of the gas storage sites signature.

For the street survey measurements, we only collected CRDS measurements which are not much reliable. The mean signature that we measured from 2 local methane enhancements among the forty ones that we detected is $-40.5 \pm 2.0 \%$. This signature is clearly not biogenic and eliminates an attribution to methane emanations from sewage facilities. It is typical from natural gas (thermogenic source) and in agreement with the value of $-39.1 \pm 1.1 \%$ reported by Widory and Javoie (2003) for the gas supply in Paris as well as with the ${ }^{13} \mathrm{CH}_{4}$ signature that we found for the gas storage site of Germigny-sous-Coulombs. Among the $1000 \mathrm{~km}$ that were surveyed in the Paris city, we found very local methane enhancements on about forty locations only, unlike in other cities of the United States of America where numerous and occasionally large methane leaks on the natural gas distribution network were found, such as in Boston (Phillips et al., 2013 ; Boothroyd et al., 2018), in Washington DC (Jackson et al., 2014) and in Los Angeles (Townsend-Small et al., 2012). Additional surveys are needed using the bag sampling technic/ GC-IRMS to attribute sources (gas pipelines leaks, sewage emanations) to the rorty of local methane enhancements that were detected in the Paris streets.

The two plumes detected at the WWT site of Achères give an average signature of $53.6 \pm 3.4 \%$ by GC-IRMS. By comparison, Phillips et al. (2013) measured a mean signature of $-53.1 \%$ for Boston main WWT plant that is consistent with our results. Toyoda et al. (2011) reported $\delta^{13} \mathrm{CH}_{4}$ enriched signatures of $-50.7 \%$ for WWT facilities in Japan. Townsend-Small et al. (2012) reported even heavier signatures of $-46.3 \%$ and $-47.0 \%$ for WWT facilities in Los Angeles and Orange counties. The causes of enrichment in ${ }^{13} \mathrm{C}$ of these plants compared to Achères and to the Boston's WWT facility is not clear. As mentionned by Townsend-Hall et al. (2012), this could be linked to denitrification processes and requires dedicated studies. However, our study reports for the first time the $\delta^{13} \mathrm{CH}_{4}$ signature of the Achères emission plumes. More surveys should be performed to assess any variability in the $\delta^{13} \mathrm{CH}_{4}$ signature of this source.

\subsection{Comparison to the regional inventory}

In this section, we compare the location of the sites and more qualitatively the strength of the methane emissions observed in our study with those of the AIRPARIF 2013 methane emissions inventory.

The AIRPARIF 2013 IDF methane emissions inventory includes all the sites that we surveyed appart the gas storage site of Gournay-sur-Aronde, which is located outside the IDF region. The location of the sites (cf Tables 1 to 4) could be slightly revised in order to reach a better accuracy when estimating emissions using fine-scale regional top-down modeling approaches. Indeed, differences of more than $10 \mathrm{~km}$ between the position given in the inventory and the actual position were detected, while the inventory is delivered at the 1 $\mathrm{km}$ scale. The latitude of the Isles-les-Meldeuses landfill is not given in the AIRPARIF inventory, although its longitude matches with the one of landfill L9. As we could not find any large landfill at the position given by AIRPARIF, we suggest that possibly the inventory does not report correctly the Isles-les-Meldeuses latitude which is located about $130 \mathrm{~km}$ eastern than suggested for landfill L9 in the inventory. Finally in the inventory, the name of Moisselles should be replaced by Attainville. 
Regarding landfills, methane plumes with local $\mathrm{CH}_{4}$ enhancements of several ppm above background were detected on 6 of the 10 main landill sites given by the inventory. The Claye-Souilly site showed a local methane concentration enhancement that was smaller that the one measured at the other landfill sites, while it is supposed to be the biggest methane emitter within the landfill sector. On that site, we might have not been close enough to the source and might have missed the strongest plume, due to the roads configuration, and/or meteorological conditions not favorable. This site would benefit from additional surveys in order to verify our results. At comparable windspeed and plume downwind exposure conditions, the Fouju-Moisenay and Isles-les-Meldeuses sites show local methane concentration enhancements as high as the landfills of Le Plessis-Gassot and Vert-le-Grand, while, according to the AIRPARIF 2013 inventory, these two first sites emit 2 to 10 times less methane that the two latter sites. But of course, we can not correlate directly the amplitude of atmospheric concentration enhancements with the intensity of source emissions. This would require dedicated atmospheric tools: it would be very interesting to investigate each emitting site further by calculating their emissions rate, for example by coupling a tracer release technique and local-scale transport modelling (Ars et al., 2017). Among the 10 sites that we studied, no local methane enhancement could be detected. For 3 of these 4 sites (Brueil-enVexin, Monthyon and Moisselles), as the sampling conditions were not satisfying, additional surveys with favorable conditions are needed on these sites (see section 3.2). The $4^{\text {th }}$ site (Epinay-Champlâtreux) was closed in 2008 and this can explain why we did not detect any methane plume downwind of this old landfill. Finally, the Guitrancourt site that now replaces the Brueil-en-Véxin site should be surveyed in a future study.

Regarding the gas storage sites of IDF, our study demonstrated the occurrence of methane leaks giving rise to local methane concentration enhancements of several ppm above background in Germigny-sous-Coulombs and Beynes, which are both estimated to emit $0.32 \mathrm{ktCH}_{4} / \mathrm{yr}$ by the inventory. We did not detect any leak at the Saint-Illiers-la-Ville and Saint-Clair-sur-Epte sites. For Saint-Illiers-la-Ville the sampling conditions were favorable to detect any methane plume. For Saint-Clair-sur-Epte, the car was maybe passing to far away from the site (see section 3.3) which could explain that we did not detect any methane enhancement on this site ; but this could be the case that this site does not emit methane at all. For these two sites, the emission rates given by AIRPARIF 2013 are 0.23 and 0.30 $\mathrm{ktCH}_{4} / \mathrm{yr}$, respectively. One explanation could be that these sites are equipped with high performance compression technology that cuts out the emissions of greenhouse gases to the atmosphere, conversely to Germigny-sous-Coulombs and Beynes (https://www.storengy.com/countries/france/en/our-sites.html) - note that the Germigny-sousCoulombs site should benefit of such improved technology in the near future. But at the Saint-Clair-sur-Epte site, as the car did not pass closer than $450 \mathrm{~m}$ downwind of the site, more surveys closer to the site downwind of it are needed there to validate this hypothesis. Therefore, we conclude that $1 /$ the AIRPARIF emissions inventory should be revised for the Saint-Illiers-la-Ville for zero emissions, 2/ additional surveys are needed on Saint-Clair-sur-Epte closer to the site ; and 3/ the Germiny-sous-Coulombs and Beynes sites should be surveyed to monitor emission mitigation resulting from future technological improvements.

Regarding the Paris streets, about forty methane concentration enhancements above background were detected and two of them could be attributed to natural gas network leaks from $\delta^{13} \mathrm{CH}_{4}$ measurements. These urban methane enhancements are much less numerous 
and intense than in some cities in North-America (Phillips et al., 2013 ; Boothroyd et al., 2018 ; Jackson et al., 2014 ; Townsend-Small et al., 2012). It is possible that the technology used to ensure the tightness of the gas lines seals in Paris is much more performant than the one in the USA. However, additional surveys are needed to attribute all of the methane enhancements detected in the Paris streets to either natural gas pipeline leaks or sewage emanations. Such leaks should then be quantified by independent top-down methods and taken into accout in the AIRPARIF inventory.

Regarding the Achères WWT site, we detected large local methane enhancements of several ppm above background. According to the inventory, this site emits only 0.066 $\mathrm{ktCH}_{4} / \mathrm{yr}$. This is much lower compared to gas storage or landfills sites that are also observed to emit methane enhancements of similar extent to the WWT site for similar wind exposure and sampling distance conditions. There could be an underestimation of methane emissions from this facility and from the WWT sector in the AIRPARIF 2013 emissions inventory, but this should be assessed by independent emission quantification methods such as the ones proposed in Ars et al. (2017). We thus conclude that dedicated campaigns should be performed on the sites surveyed in our study in order to compute estimates of their methane emissions and to answer whether the AIRPARIF inventory can be validated or should be revised.

\section{Acknowledgements}

We thank AIRPARIF and especially Olivier Perrussel for access to the AIRPARIF 2013 methane emissions inventory. We are grateful to PICARRO and especially Renato Winkler for their key contribution to the mobile campaigns and CRDS data collection. The first author is greatful to A. Remy for his help with collecting information on the sites. We thank $L$. Brégonzio-Rozier for helping with collecting measurements in the field. This work was supported by the InGOS EU-FP7 TRANS-NATIONAL program, by the KIC-CLIMAT CARBOCOUNT-CITY project and by Institut Pierre Simon Laplace.

\section{References}

Akritas, M.G., Bershady, M.A., 1996. Linear regression for astronomical data with measurement errors and intrinsic scatter. Astrophys. J. 470, 706-714, doi:10.1086/177901

Ars, S., Broquet, G., Yver Kwok, C., Roustan, Y., Wu, L., Arzoumanian, E., Bousquet, P., 2017. Statistical atmospheric inversion of local gas emissions by coupling the tracer release technique and local-scale transport modelling: a test case with controlled methane emissions, Atmos. Meas. Tech., 10, 5017-5037, https://doi.org/10.5194/amt-10-5017-2017

Arata, C., Rahn, T., Dubey, M.K., 2016. Methane Isotope Instrument Validation and Source Identification at Four Corners, New Mexico, United States, J. Phys. Chem. A, 120, 9, 14881494, https://doi.org/10.1021/acs.jpca.5b12737

Assan, S., Baudic, A., Guemri, A., Ciais, P., Gros, V., Vogel, F.R., 2017. Characterization of interferences to in situ observations of $\delta^{13} \mathrm{CH}_{4}$ and $\mathrm{C}_{2} \mathrm{H}_{6}$ when using a cavity ring-down spectrometer at industrial sites, Atmos. Meas. Tech., 10, 2077-209, https://doi.org/10.5194/amt-10-2077-2017 
Bergamaschi, P., Lubina, C., Königstedt, R., Fischer, H., Veltkamp, A. C., Zwaagstra, O., 1998b. Stable isotopic signatures $\left(\delta^{13} \mathrm{C}, \delta \mathrm{D}\right)$ of methane from European landfill sites, J. Geophys. Res.-Atmos., 103, 8251-8265, DOI : 10.1029/98jd00105

Boothroyd, I.M., Almond, S., Worrall, F., Davies, R.K., Davies, R.J., 2018. Assessing fugitive emissions of $\mathrm{CH}_{4}$ from high-pressure gas pipelines in the UK, Science of the Total Environment, 631-632, 1638-1648, https://doi.org/10.1016/j.scitotenv.2018.02.240

Börjesson, G., Chanton, J., Svensson, B.H., 2001. Methane oxidation in two Swedish landfill covers measured with carbon-13 to carbon-12 isotope ratios, J. Environ. Qual., 30 (2), 369376, doi: 10.2134/jeq2001.302369x

Bousquet, P., Ciais, P., Miller, J., Dlugokencky, E., Hauglustaine, D., Prigent, C., Van der Werf, G., Peylin, P., Brunke, E.-G., Carouge, C., 2006. Contribution of anthropogenic and natural sources to atmospheric methane variability. Nature 443, 439-443, doi: $10.1038 /$ nature 05132

Dlugokencky, E., 2018. NOAA/ESRL (www.esrl.noaa.gov/gmd/ccgg/trends_ch4/, 21 sept.2018

Dluglokencky, E., Nisbet, E., Fisher, R., Lowry, D., 2011. Global atmospheric methane: budget, changes and dangers, Ph) il. Trans. R. Soc. A (2011) 369, 2058-2072, doi:10.1098/rsta.2010.03414

Duren, R. M., Miller, C. E., 2012. Measuring the carbon emissions of megacities, Nat. Clim. Change, 2, 560-562, https://doi.org/10.1038/nclimate1629

Fisher, R.E., Sriskantharajah, S., Lowry, D., Lanoisellé, M., Fowler, C. M. R., James, R. H., Hermansen, O., Lund Myhre, C., Stohl, A., Greinert, J., Nisbet-Jones, P. B. R., Mienert, J., Nisbet, E. G., 2011. Arctic methane sources: Isotopic evidence for atmospheric inputs, Geophys. Res. Lett., 38, L21803, doi:10.1029/2011GL049319.

Gasser, T., Ciais, P., Boucher, O., Quilcaille, Y., Tortora, M, Bopp., L, Hauglustaine, D., 2017. The compact Earth system model OSCAR v2. 2: description and first results. Geoscientific Model Development, 10(1), 271-319, doi:10.5194/gmd-10-271-2017

Houweling, S., Bergamaschi, P., Chevallier, F., Heimann, M., Kaminski, T., Krol, M., Michalak, A. M., Patra, P., 2017. Global inverse modeling of $\mathrm{CH}_{4}$ sources and sinks: an overview of methods, Atmos. Chem. Phys., 17, 235-256, https://doi.org/10.5194/acp-17-235$\underline{2017}$

Hsu, Y.K., Van Curen, T., Parka, S., Jakober, C., Herner, J., FitzGibbon, M., Blake, D.R., Parrish, D.D., 2010. Methane emissions inventory verification in southern California, Atmosph. Envir. 44 (1), 1-7, doi:10.1016/j.atmosenv.2009.10.002

Intergovernmental Panel on Climate Change, 2006. IPCC guidelines for national greenhouse gas inventories, Intergovernmental Panel on Climate Change (https://www.ipccnggip.iges.or.jp/public/2006gl/)

Karion, A., Sweeney, C., Pétron, G., Frost, G., Hardesty, R.G., Kofler, J., Miller, B.J., Newberger, T., Wolter, S., Banta, R., Brewer, A., Dlugokencky, E., Lang, P., Montzka, S.A., Schnell, R., Tans, P., Trainer, M., Zamora, R., Conley, S., 2013. Methane emissions estimate from airborne measurements over a western United States natural gas field. Geophys. Res. Lett. 40 (16), 4393-4397, http://dx.doi.org/10.1002/grl.50811 
Keeling, C.D., 1958. The concentration and isotopic abundances of atmospheric carbon dioxide in rural areas, Geochim. Cosmochim. Acta 13, 322-334.

Jackson, R.B., Down, A., Phillips, N.G., Ackley, R.C., Cook, C.W., Plata, D.L., Zhao, K., 2014. Natural Gas Pipeline Leaks Across Washington, DC, Environ. Sci. Technol. 48, 3, 2051-2058, doi: 10.1021/es404474x

Lassey, K.R., Allan, W., Fletcher, S.E.M., 2011. Seasonal inter-relationships in atmospheric methane and companion delta C-13 values: effects of sinks and sources, Tellus Ser. B : Chem. Phys. Meteorol. 63, 287-301, https://doi.org/10.1111/j.1600-0889.2011.00535.x

Liptay, K., Chanton, J., Czeiel, P., Mosher, B., 1998. Use of stable isotopes to determine methane oxidation in landfill cover soils, J. Geophys. Res. Atmos. (1984-2012), 103 , 82438250, https://doi.org/10.1029/97JD02630

Lopez, M., Sherwood, O.A., Dlugokencky, E.J., Kessler, R., Giroux, L., Worthy, D.E.J., 2017. Isotopic signatures of anthropogenic $\mathrm{CH}_{4}$ sources in Alberta, Canada, Atmosph. Environ.164, 280-288, https://doi.org/10.1016/j.atmosenv.2017.06.021

Lowry, D., Holmes, C.W., Rata, N.D., O'Brien, P., Nisbet, E.G., 2001. London methane emissions: use of diurnal changes in concentration and $\delta^{13} \mathrm{C}$ to identify urban sources and verify inventories, J. Geophys. Res. Atmos., 106, 7427-7448, https://doi.org/10.1029/2000JD900601

McKain, K. , Down, A., Racitie, S.M., Budneya, J., Hutyra, L.R., Floerchinger, C., Herndon, S.C., Nehrkornh, T., Zahniserg , M.S., Jackson, R.B., Phillips, N., Wofsy, S.C., 2015. Methane emissions from natural gas infrastructure and use in the urban region of Boston, Massachusetts, PNAS 112 (7), 1941-1946, doi: 10.1073/pnas.1416261112

Mikaloff Fletcher, S.E., Tans, P.P., Bruhwiler, L.M., Miller, J.B., Heimann, M., 2004. $\mathrm{CH}_{4}$ sources estimated from atmospheric observations of $\mathrm{CH}_{4}$ and its ${ }^{13} \mathrm{C} /{ }^{12} \mathrm{C}$ isotopic ratios: 1 . Inverse modeling of source processes, Global Biogeochem. Cycles, 18, GB4004, 17 pp., doi:10.1029/2004GB002223

Miller, S.M., Wofsy, S.C., Michalak, A.M., Kort, E.A., Andrews, A.E., Biraud, S.C., Dlugokencky, E.J, Eluszkiewicz, J., Fischer, M.L., Janssens-Maenhout, G., Miller, B.R., Miller, J.B., Montzka, S.A., Nehrkorn, T., Sweeney, C., 2013. Anthropogenic emissions of methane in the United States., Proc. Nat. Acad. Sci. 110 (50), 20018-20022. http://dx.doi.org/10.1073/pnas.1314392110

Monteil, G., Houweling, S., Dlugockenky, E., Maenhout, G., Vaughn, B., White, J., Rockmann, T., 2011. Interpreting methane variations in the past two decades using measurements of $\mathrm{CH}_{4}$ mixing ratio and isotopic composition. Atmos.Chem. Phys. 11, 91419153, https://doi.org/10.5194/acp-11-9141-2011

Montzka, S. A., Dlugokencky, E., Butler, J.H., 2011. Non-greenhouse gases and climate change Nature 476, 43-50, doi: 10.1038/nature10322

Nisbet, E.G., Manning, M. R., Dlugokencky, E. J., Fisher, R. E., Lowry, D., Michel, S. E., Lund Myhre, C., Platt, S. M., Allen, G., Bousquet, P., Brownlow, R., Cain, M., France, J. L., Hermansen, O., Hossaini, R., Jones, A. E., Levin, I., Manning, A. C. ,Myhre, G., Pyle, J. A., Vaughn, B., Warwick, N. J., White, J. W. C., 2019. Very strong atmospheric methane growth in the four years 2014-2017: Implications for the Paris Agreement, Global Biogeochem. Cycles, accepted, doi :1029/2018GB006009 
Nisbet, E.G., Dlugokencky, E.J., Manning, M. R. , Lowry, D., Fisher, R. E., France, J. L., Michel, S. E., Miller, J. B. , White, J. W. C., Vaughn, B., Bousquet, P. , Pyle, J. A., Warwick, N. J., Cain, M., Brownlow, R., Zazzeri, G., Lanoisellé, M., Manning, A. C. , Gloor, E., Worthy, D. E. J., Brunke, E.-G., Labuschagne, C., Wolff, E. W., Ganesan, L., 2016. Rising atmospheric methane: 2007-2014 growth and isotopic shift, Global Biogeochem. Cycles, 30, 1356-1370, doi:10.1002/2016GB005406.

Nisbet, E.G., Dlugokencky, E.J., Bousquet, P., 2014. Methane on the rise - again, Science 343, 493-495, doi: 10.1126/science.1247828

ORDIF 2013, IAU-îdf 2013, ATLAS des installations de traitement de déchets 2012 - 2013, ORDIF editions, May 2014 (https://www.actu-environnement.com/media/pdf/news-22130atlas-ordif.pdf)

Phillips, N.G., Ackley, R., Crosson, E.R., Down, A., Hutyra, L. R., Brondfield, M., Karr, J.D., Zhao, K., Jackson, R.B., 2013. Mapping urban pipeline leaks: Methane leaks across Boston, Environmental Pollution, 173, 2013, 1-4, https://doi.org/10.1016/i.envpol.2012.11.003

Picarro, 2012. Picarro Mobile Kit User's Guide 40047 Revision B, p. 18.

Rella, C.W., Hoffnagle, J., He, J., Tajima, S., 2015. Local- and regional-scale measurements of $\mathrm{CH}_{4}, \delta^{13} \mathrm{CH}_{4}$, and $\mathrm{C}_{2} \mathrm{H}_{6}$ in the Uintah Basin using a mobile stable isotope analyzer, Atmos. Meas. Tech., 8, 4539-4559, doi:10.5194/amt-8-4539-2015

Saunois, M., Bousquet, P., Poulter, B., Peregon, A., Ciais, P., Canadell, J. G., Dlugokencky, E. J., Etiope, G., Bastviken, D., Houweling, S., Janssens-Maenhout, G., Tubiello, F. N., Castaldi, S., Jackson, R. B., Alexe, M., Arora, V. K., Beerling, D. J., Bergamaschi, P., Blake, D. R., Brailsford, G., Brovkin, V., Bruhwiler, L., Crevoisier, C., Crill, P., Covey, K., Curry, C., Frankenberg, C., Gedney, N., Höglund-Isaksson, L., Ishizawa, M., Ito, A., Joos, F., Kim, H.S., Kleinen, T., Krummel, P., Lamarque, J.-F., Langenfelds, R., Locatelli, R., Machida, T., Maksyutov, S., McDonald, K. C., Marshall, J., Melton, J. R., Morino, I., Naik, V., O'Doherty, S., Parmentier, F.-J. W., Patra, P. K., Peng, C., Peng, S., Peters, G. P., Pison, I., Prigent, C., Prinn, R., Ramonet, M., Riley, W. J., Saito, M., Santini, M., Schroeder, R., Simpson, I. J., Spahni, R., Steele, P., Takizawa, A., Thornton, B. F., Tian, H., Tohjima, Y., Viovy, N., Voulgarakis, A., van Weele, M., van der Werf, G. R., Weiss, R., Wiedinmyer, C., Wilton, D. J., Wiltshire, A., Worthy, D., Wunch, D., Xu, X., Yoshida, Y., Zhang, B., Zhang, Z., Zhu, Q., 2016. The global methane budget 2000-2012, Earth Syst. Sci. Data, 8, 697-751, https://doi.org/10.5194/essd-8-697-2016

Saunois, M., Bousquet, P., Poulter, B., Peregon, A., Ciais, P., Canadell, J. G., Dlugokencky, E. J., Etiope, G., Bastviken, D., Houweling, S., Janssens-Maenhout, G., Tubiello, F. N., Castaldi, S., Jackson, R. B., Alexe, M., Arora, V. K., Beerling, D. J., Bergamaschi, P., Blake, D. R., Brailsford, G., Bruhwiler, L., Crevoisier, C., Crill, P., Covey, K., Frankenberg, C., Gedney, N., Höglund-Isaksson, L., Ishizawa, M., Ito, A., Joos, F., Kim, H.-S., Kleinen, T., Krummel, P., Lamarque, J.-F., Langenfelds, R., Locatelli, R., Machida, T., Maksyutov, S., Melton, J. R., Morino, I., Naik, V., O'Doherty, S., Parmentier, F.-J. W., Patra, P. K., Peng, C., Peng, S., Peters, G. P., Pison, I., Prinn, R., Ramonet, M., Riley, W. J., Saito, M., Santini, M., Schroeder, R., Simpson, I. J., Spahni, R., Takizawa, A., Thornton, B. F., Tian, H., Tohjima, Y., Viovy, N., Voulgarakis, A., Weiss, R., Wilton, D. J., Wiltshire, A., Worthy, D., Wunch, D., Xu, X., Yoshida, Y., Zhang, B., Zhang, Z., Zhu, Q., 2017. Variability and quasi-decadal changes in the methane budget over the period 2000-2012, Atmos. Chem. Phys., 17, 11135-11161, https://doi.org/10.5194/acp-17-11135-2017 
Schwietzke, S., Sherwood, O.A., Bruhwiler, L.M., Miller, J.B., Etiope,G., Dlugokencky, E.J., Michel, S.E., Arling, V.A., Vaughn, B.H., White, J.W., Tans, P.P., 2016. Upward revision of global fossil fuel methane emissions based on isotope database. Nature 538 (7623), 88e91. http://dx.doi.org/10.1038/nature19797

Schwietzke, S., Pétron, G., Conley, S., Pickering, C., Mielke-Maday, I., Dlugokencky, E.J., Tans, P.P., Vaughn, T., Bell, C., Zimmerle, D., Wolter, S., King, C.W., White, A.B., Coleman, T., Bianco, L., Schnell, R.C., 2017. Improved Mechanistic Understanding of Natural Gas Methane Emissions from Spatially Resolved Aircraft Measurements, Environmental Science \& Technology 201751 (12), 7286-7294, doi: 10.1021/acs.est.7b01810

Sherwood, O., Schwietzke, S., Arling, V., Etiope, G., 2016. Global Inventory of Fossil and Non-fossil Methane $\delta^{13} \mathrm{C}$ Source Signature Measurements for Improved Atmospheric Modeling, http://doi.org/10.15138/G37P4D

Townsend-Small, A., Tyler, S.C., Pataki, D. E., Xu, X., Christensen, L. E., 2012. Isotopic measurements of atmospheric methane in Los Angeles, California, USA: Influence of "fugitive" fossil fuel emissions, J. Geophys. Res., 117, D07308, doi:10.1029/2011JD016826.

Townsend-Small, A., Pataki, D. E., Tseng, L. Y., Tsai, C. Y., Rosso, D., 2011b. Nitrous oxide emissions from wastewater treatment and water reclamation plants in southern California, J. Environ. Qual., 40, 1542-1550, doi:10.2134/jeq2011.0059.

Toyoda, S., Suzuki, Y., Hattori, S., Yamada, K,. Fujii, A. Yoshida, N., Kuono, R. Murayama, K., Shiomi, H., 2011. Isotopomer analysis ofproduction and consumption mechanisms of $\mathrm{N}_{2} \mathrm{O}$ and $\mathrm{CH}_{4}$ in an advancedwastewater treatment system, Environ. Sci. Technol.,45, 917922,doi:10.1021/es102985u

von Fischer, J.C., Cooley, D., Chamberlain, S., Gaylord, A., Griebenow C.J., Hamburg, S.P., Salo, J., Schumacher, R., Theobald, D., Ham, J., 2017. Rapid, vehicle-based identification of location and magnitude of urban natural gas pipeline leaks. Environmental Science \& Technology, 51(7), 4091-9, doi: 10.1021/acs.est.6b06095

Weller, Z.D., Roscioli, J.R., Daube, W.C., Lamb, B.K., Ferrara, T.W., Brewer, P.E., von Fischer, J.C., 2018. Vehicle-based methane surveys for finding natural gas leaks and estimating their size: Validation and uncertainty. Environmental science \& technology, 52(20):11922-30, http://doi.org/10.1021/acs.est.8b03135

Widory, D., Javoie, M., 2003. The carbon isotope composition of atmospheric $\mathrm{CO}_{2}$ in Paris, Earth and Planetary Science Letters, 215 (1-2), 289-298, http://doi.org/10.1016/S0012$\underline{821 \times(03) 00397-2}$

Whiticar, M.J., 1999. Carbon and hydrogen isotope systematics of bacterial formation and oxidation of methane. Chem. Geol. 161, 291e314, http://dx.doi.org/10.1016/S00092541(99)00092-3

Xueref-Remy, I., Dieudonné, E., Vuillemin, C., Lopez, M., Lac, C, Schmidt, M., Delmotte, M., Chevallier, F., Ravetta, F., Perrussel, O., Ciais, P., Bréon, F.M., Broquet, G., Ramonet, M., Spain, G., Ampe, C., 2018. Diurnal, synoptic and seasonal variability of atmospheric $\mathrm{CO}_{2}$ in the Paris megacity area, Atmos. Chem. Phys., 18, 3335-3362, https://doi.org/10.5194/acp$\underline{18-3335-2018}$ 
1187 Zazzeri, G., Lowry, D., Fisher, R.E., France, J.L., Lanoisellé, M., Nisbet, E.G., 2015. Plume 1188 mapping and isotopic characterization of anthropogenic methane sources, Atmosph. Envir. 1189 110, 151-162, https://doi.org/10.1016/j.atmosenv.2015.03.029

1190 Zazzeri, G., Lowry, D., Fisher, R.E., France, J.L., Lanoisellé, M., Grimmond, S.C.B, Nisbet, 1191 E.G., 2017. Evaluating methane inventories by isotopic analysis in the London region, 1192 Scientific Reports | 7: 4854, 13 pp., https://doi.org/10.1038/s41598-017-04802-6.

\section{Declaration of interests}

$\bigotimes$ The authors declare that they have no known competing financial interests or personal relationships that could have appeared to influence the work reported in this paper.

$\square$ The authors declare the following financial interests/personal relationships which may be considered as potential competing interests: 